WSRC-TR-2004-00509

Revision 0

Key Words: Wetlands

Metal

Waste Water Treatment

\title{
Review of Constructed Subsurface Flow vs. Surface Flow Wetlands
}

\author{
Nancy V. Halverson
}

September 2004

Westinghouse Savannah River Company

Savannah River Site

Aiken, SC 29808

Prepared for the U.S. Department of Energy Under

Contract Number DE-AC09-96SR18500 
This document was prepared in conjunction with work accomplished under Contract No. DE-AC09-96SR18500 with the U. S. Department of Energy.

\section{DISCLAIMER}

This report was prepared as an account of work sponsored by an agency of the United States Government. Neither the United States Government nor any agency thereof, nor any of their employees, makes any warranty, express or implied, or assumes any legal liability or responsibility for the accuracy, completeness, or usefulness of any information, apparatus, product or process disclosed, or represents that its use would not infringe privately owned rights. Reference herein to any specific commercial product, process or service by trade name, trademark, manufacturer, or otherwise does not necessarily constitute or imply its endorsement, recommendation, or favoring by the United States Government or any agency thereof. The views and opinions of authors expressed herein do not necessarily state or reflect those of the United States Government or any agency thereof.

This report has been reproduced directly from the best available copy.

Available for sale to the public, in paper, from: U.S. Department of Commerce, National Technical Information Service, 5285 Port Royal Road, Springfield, VA 22161, phone: (800) 553-6847, fax: (703) 605-6900

email: orders@ntis.fedworld.gov

online ordering: http://www.ntis.gov/help/index.asp

Available electronically at http://www.osti.gov/bridge

Available for a processing fee to U.S. Department of Energy and its contractors, in paper, from: U.S. Department of Energy, Office of Scientific and Technical Information, P.O. Box 62, Oak Ridge, TN 37831-0062,

phone: (865)576-8401,

fax: (865)576-5728

email: $\underline{\text { reports@ adonis.osti.gov }}$ 


\section{TABLE OF CONTENTS}

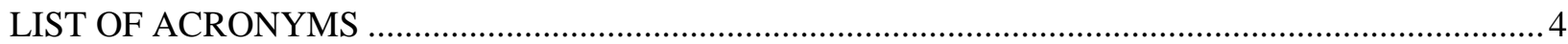

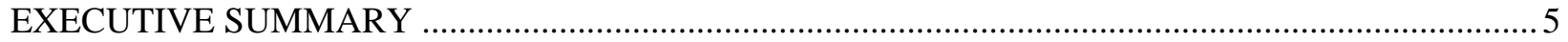

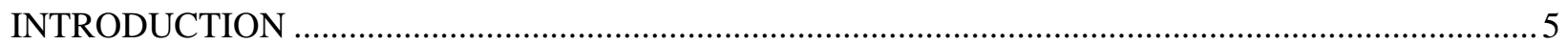

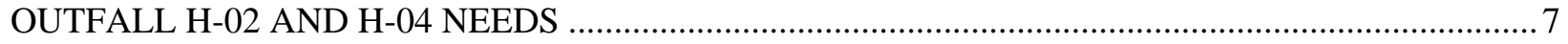

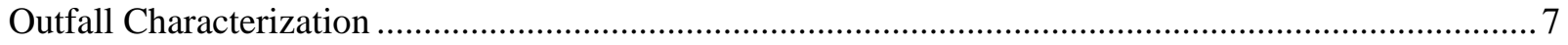

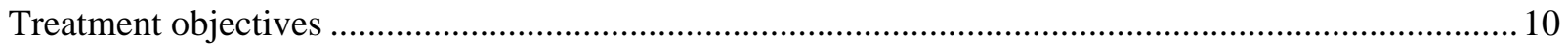

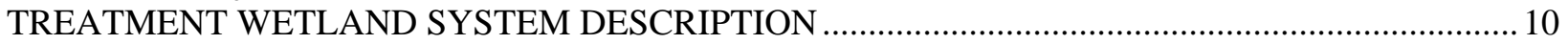

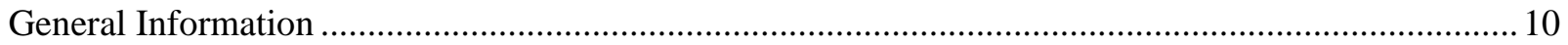

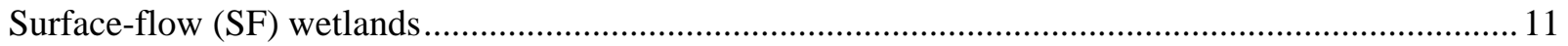

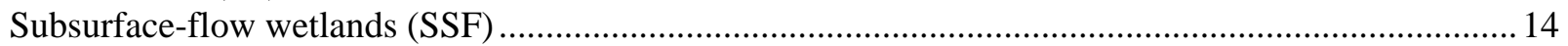

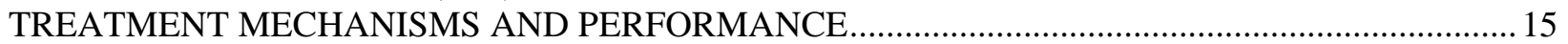

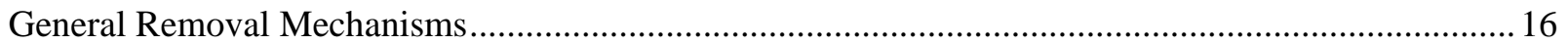

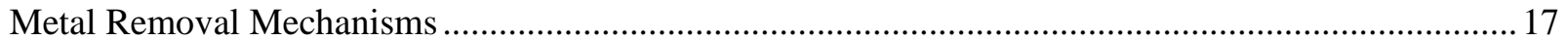

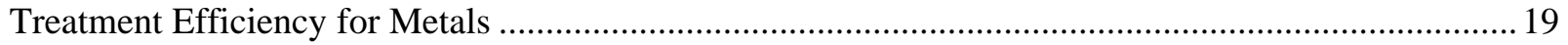

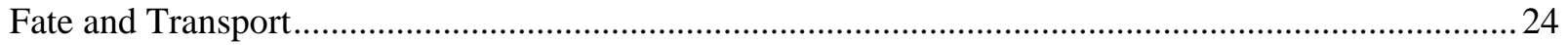

SUITABILITY OF SUBSURFACE-FLOW WETLANDS FOR THIS APPLICATION.......................... 25

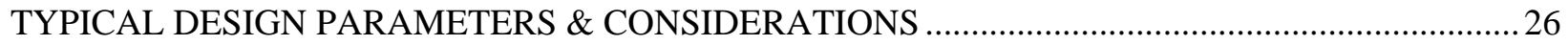

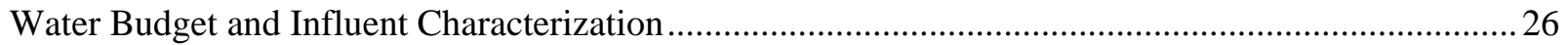

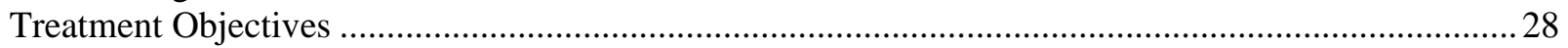

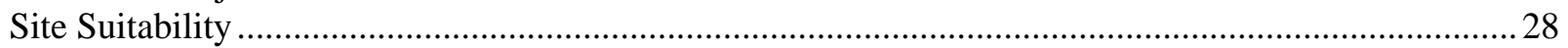

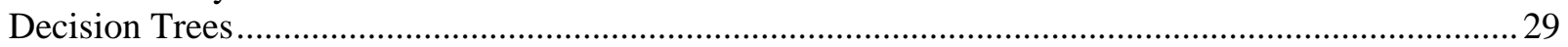

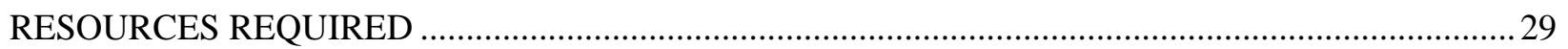

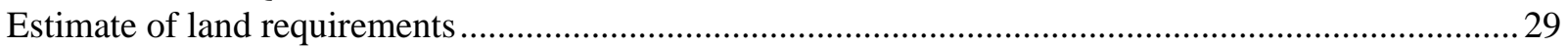

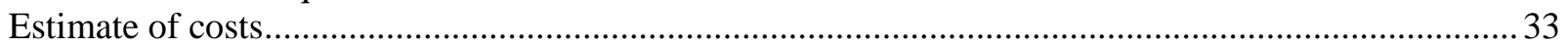

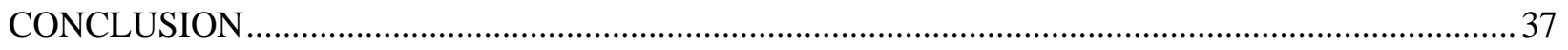

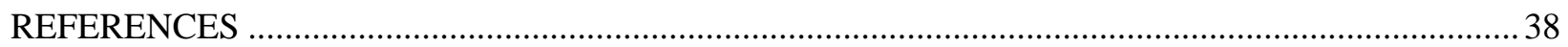

\section{TABLE OF FIGURES}

Figure 1. Location of Outfalls H-02 and H-04 ......................................................................... 7

Figure 2. Surface Flow vs. Subsurface Flow Constructed Wetland ...................................................... 13

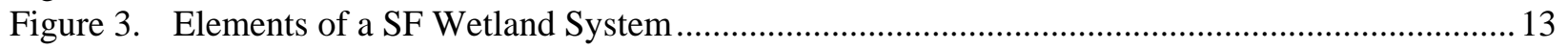

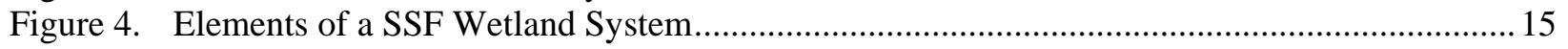

Figure 5. Typical Cross-Section of a SSF Wetland Cell ................................................................... 15

Figure 6. Mechanisms Treating Inorganic Compounds in Wetland Treatment Systems ........................17

Figure 7. Mechanisms for Metals Removal in Wetlands ..................................................................... 18

Figure 8. Constructed Wetland Site Selection Decision Tree ..........................................................2 27

Figure 9. Decision Tree for Remedial Wastewaters ............................................................................... 30

\section{TABLE OF TABLES}

Table 1. General Characterization of the Outfalls H-02 and H-04 ................................................. 8

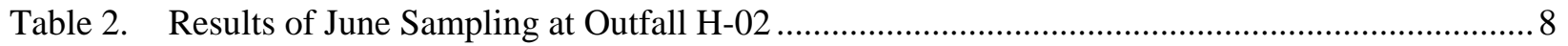

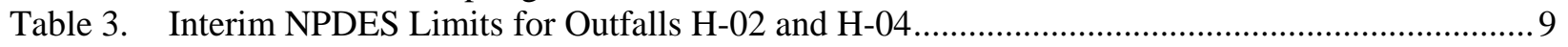

Table 4. Final NPDES Limits for Outfalls H-02 and H-04 ........................................................

Table 5. Constituents Above NPDES Limits and Required Removal Rates ......................................... 10

Table 6. Advantages and Disadvantages of Surface Flow and Subsurface Flow Wetlands .................... 12 
Table 7. Examples of Metals Removal in Wetland Treatment Systems...............................................20

Table 8. Copper, Zinc and Lead Removal at Various SSF Wetlands....................................................22

Table 9. Typical Influent Concentrations and Removal Efficiencies for Three Types of Wastewaters.. 24

Table 10. Rule of Thumb Design Criteria for SSF and SF Constructed Treatment Wetlands.................. 32

Table 11. Estimated Minimum Wetland Surface Area for Combined Outfalls H-02 and H-04 ............... 33

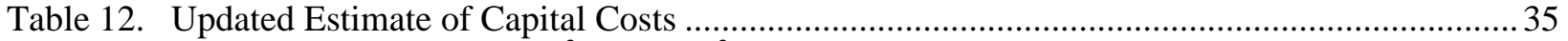

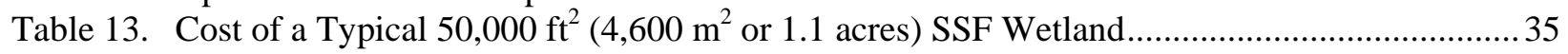

Table 14. Updated Estimate of O\&M Costs ....................................................................................... 36

Table 15. Preliminary Cost Comparison of a SSF vs. a SF Wetland for Outfalls H-02 and H-04 ........... 37

\section{LIST OF ACRONYMS}

BOD Biochemical Oxygen Demand

CERCLA Comprehensive Environmental Response Compensation and Liability Ac

cwt Hundredweight, unit of weight equivalent to 100 pounds

ENR Engineering News Record

ha Hectare

MR Monitor and Report

NPDES National Pollution Discharge Elimination System

O\&M Operations and Maintenance

RCRA Resource Conservation and Recovery Act

SF $\quad$ Surface Flow

SRS Savannah River Site

SSF $\quad$ Subsurface Flow

su Standard Units

TSS Total Suspended Solids 


\section{EXECUTIVE SUMMARY}

The purpose of this document is to utilize existing documentation to review the effectiveness of subsurface flow and surface flow constructed wetlands in treating wastewater and to demonstrate the viability of treating effluent from Savannah River Site outfalls H-02 and H-04 with a subsurface flow constructed wetland to lower copper, lead and zinc concentrations to within National Pollutant Discharge Elimination System (NPDES) Permit limits. Constructed treatment wetlands are engineered systems that have been designed and constructed to utilize the natural functions of wetlands for wastewater treatment. Constructed wetlands have significantly lower total lifetime costs and often lower capital costs than conventional treatment systems.

The two main types of constructed wetlands are surface flow and subsurface flow. In surface flow constructed wetlands, water flows above ground. Subsurface flow constructed wetlands are designed to keep the water level below the top of the rock or gravel media, thus minimizing human and ecological exposure. Subsurface flow wetlands demonstrate higher rates of contaminant removal per unit of land than surface flow (free water surface) wetlands, therefore subsurface flow wetlands can be smaller while achieving the same level of contaminant removal.

Wetlands remove metals using a variety of processes including filtration of solids, sorption onto organic matter, oxidation and hydrolysis, formation of carbonates, formation of insoluble sulfides, binding to iron and manganese oxides, reduction to immobile forms by bacterial activity, and uptake by plants and bacteria. Metal removal rates in both subsurface flow and surface flow wetlands can be high, but can vary greatly depending upon the influent concentrations and the mass loading rate. Removal rates of greater than $90 \%$ for copper, lead and zinc have been demonstrated in operating surface flow and subsurface flow wetlands.

The constituents that exceed NPDES limits at outfalls $\mathrm{H}-02$ and $\mathrm{H}-04$ are similar in nature and within typical concentrations found in municipal wastewaters, mine drainage and landfill leachate, all of which have been successfully treated in constructed wetlands. Contaminant-specific removal rates required to bring outfall H-02 and H-04 effluents to within NPDES limits have been achieved by various types of wetlands, including SSF wetlands. Therefore a constructed wetland would be a viable approach for treating effluent from the two outfalls.

SSF wetlands generally can be smaller than SF wetlands for a particular wastewater flow, but can cost more per acre. Thus the potential range of costs for constructing a SSF system may overlap with the cost range predicted for a SF system. However, capital costs and operations and maintenance costs for both SSF and SF wetland treatment systems are lower than for conventional wastewater treatment systems. Preliminary scoping level cost estimates for a SSF and a SF system for outfalls H-02 and H-04 are presented in this document using a range of values found in the literature.

\section{INTRODUCTION}

The purpose of this document is to utilize existing documentation to review the effectiveness of subsurface flow and surface flow constructed wetlands in treating wastewater and to demonstrate the viability of treating effluent from Savannah River Site (SRS) outfalls H-02 and H-04 to meet National Pollutant Discharge Elimination System (NPDES) Permit limits using a subsurface flow constructed 
wetland. Concentrations of copper, lead and zinc currently exceed the final limits specified in the NPDES Permit for one or both of these outfalls.

Wetland systems have always served as natural water treatment systems. During the past few decades people have seriously studied and utilized wetland systems for meeting wastewater treatment and water quality objectives in a controlled manner. The role of wetlands as a passive approach to improving water quality is a compelling argument for preserving natural wetlands and, in recent years, constructing wetlands systems for wastewater treatment.

Increasingly, studies have provided evidence that wetlands systems can effectively improve water quality while providing many benefits, including food and habitat for wildlife. However, there are concerns over potential harmful effects from toxic constituents and pathogens in many wastewater sources. Also, there are concerns that using natural wetlands for wastewater treatment may result in long-term degradation of the wetlands due to the added nutrients and altered hydrologic conditions of these systems. These potential benefits and concerns have promoted a growing interest in the use of constructed wetlands for wastewater treatment (USEPA 1993c).

Constructed treatment wetlands are engineered systems that have been designed and constructed to utilize the natural functions of wetland vegetation, soils, and their microbial populations to treat contaminants in surface water, groundwater, or waste streams (ITRC 2003, USEPA 1993c). Constructed wetlands can be considered treatment systems that use natural processes to stabilize, sequester, accumulate, degrade, metabolize, and/or mineralize contaminants. Although constructed wetland applications were limited to treating primarily storm water and municipal wastewaters, they are now being used in new applications and on new contaminants. Constructed wetlands are proving to be a valid treatment option for acid mine drainage, hazardous waste site wastewaters, petroleum refinery wastes, compost and landfill leachates, agricultural wastes and pretreated industrial wastewaters, such as those from pulp and paper mills and textile mills (ITRC 2003, USDA 1995). The technology is now mature and tested.

Constructed wetland treatment systems use rooted wetland plants and shallow, flooded or saturated soil to provide wastewater treatment. Constructed wetlands are designed to take advantage of the chemical and biological processes of natural wetlands to remove contaminants from the wastewater (Skousen 2004). Wetlands possess a rich microbial population in the sediment to bring about the biochemical transformation of pollutants, are biologically productive, and are self-sustaining. Constructed wetlands also have significantly lower total lifetime costs and often lower capital costs than conventional treatment systems (ITRC 2003). Compared to conventional systems, natural systems can be operated using less electricity and less labor (USEPA 1988).

Additionally, constructed wetlands:

- tolerate fluctuations in flow and pollutant concentrations,

- provide flood protection,

- can be built to fit into the landscape,

- provide habitats for plants and wildlife,

- enhance aesthetics of open spaces,

- provide recreational and educational opportunities, and

- are an "environmentally sensitive” approach viewed favorably by the general public and regulatory agencies (ITRC 2003)

Because the wetland constructed for the A-01 outfall has successfully brought the outfall into compliance with the NPDES permit limits, wetland treatment can be considered a potential option for other outfalls at 
SRS. Constructed wetland treatment is being considered as an appropriate passive treatment of effluent at outfalls $\mathrm{H}-02$ and $\mathrm{H}-04$.

\section{OUTFALL H-02 AND H-04 NEEDS}

\section{Outfall Characterization}

The H-02 outfall receives non-process cooling water, steam condensate, and storm water runoff from storm drains and roof drains associated with the Replacement Tritium Facility. The H-02 outfall has a long-term average flow of 0.12 million gallons per day (mgd) $\left(450 \mathrm{~m}^{3} / \mathrm{d}\right)$ and a maximum daily flow of $2.13 \mathrm{mgd}\left(8,060 \mathrm{~m}^{3} / \mathrm{d}\right)$. The discharge from H-02 flows for approximately 200 meters before entering the headwaters of Crouch Branch. Crouch Branch, a tributary of Upper Three Runs, enters Upper Three Runs approximately 0.9 miles $(1.5 \mathrm{~km})$ downstream from Road F. Biological and chemical analyses conducted in Crouch Branch indicate that the stream ecosystem is impaired due to heavy metals (primarily copper) (Specht 2004). See Figure 1 for a map of the area.

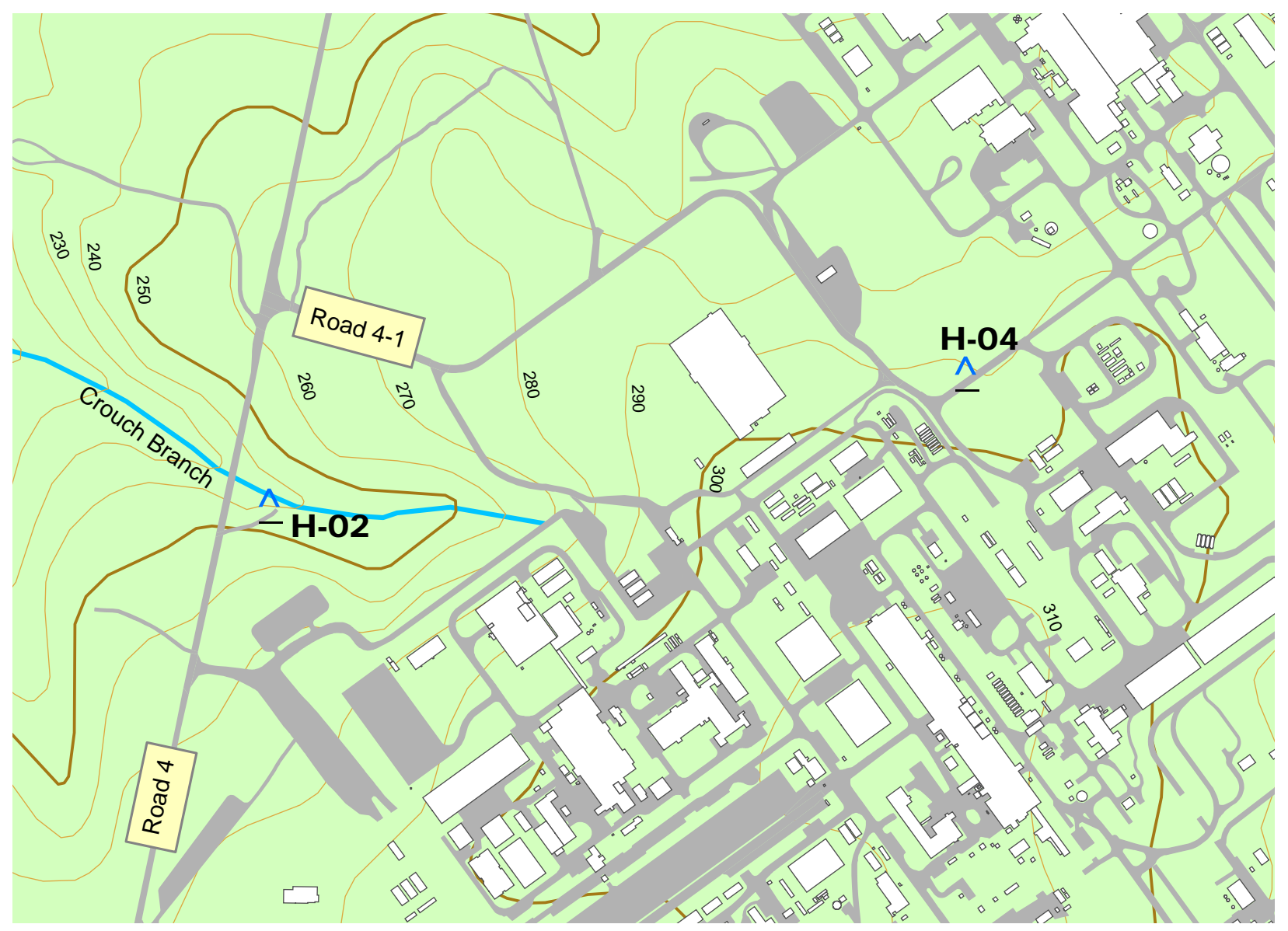

Figure 1. Location of Outfalls H-02 and H-04

The H-04 outfall receives nonprocess cooling water from the $\mathrm{H}$ Canyon, Canyon auxiliary steam condensate and storm water runoff. The H-04 outfall has a long-term average flow of $0.01 \mathrm{mgd}\left(40 \mathrm{~m}^{3} / \mathrm{d}\right)$ 
and a maximum daily flow of $0.2 \mathrm{mgd}\left(800 \mathrm{~m}^{3} / \mathrm{d}\right)$. The discharge from $\mathrm{H}-04$ flows $410 \mathrm{~m}$ in an open ditch to an unnamed tributary of Crouch Branch (Specht 2004). See Figure 1 for a map of the area.

Flow and monitored pollutant concentrations for the two outfalls are shown in Table 1. Results of metals, anions and other analyses on samples collected at outfall H-02 in June are shown in Table 2.

The NPDES permit conditions for the H-02 outfall specify Interim Limits (Table 3), which are in effect until October 31, 2008 and Final Limits (Table 4), which are in effect from November 1, 2008 through the expiration date of the NPDES permit. The NPDES permit conditions for the H-04 outfall specify Interim Limits (Table 3), which are in effect until November 30, 2006 and Final Limits (Table 4), which are in effect from December 1, 2006 through the expiration date of the NPDES permit.

Table 1. General Characterization of the Outfalls H-02 and H-04

\begin{tabular}{|l|c|c|c|c|c|c|c|}
\hline & \multirow{2}{*}{$\begin{array}{c}\text { Wastewater } \\
\text { Stream Flow } \\
\text { Rates, Average } \\
\text { Outfall }\end{array}$} & \multicolumn{6}{|c|}{ Pollutant Concentrations, Mean (Range) } \\
\cline { 3 - 8 } & \begin{tabular}{c} 
(Maximum) \\
\cline { 3 - 8 }
\end{tabular} & TSS & $\mathbf{C u}$ & $\mathbf{P b}$ & $\mathbf{Z n}$ & $\mathbf{H g}$ \\
\hline $\mathrm{H}-02$ & $\begin{array}{c}0.12(2.13)^{\mathrm{a}} \mathrm{mgd} \\
450(8,060) \mathrm{m}^{3} / \mathrm{d}\end{array}$ & $\begin{array}{c}7.2 \\
(6.7-7.6)^{\mathrm{b}}\end{array}$ & $\begin{array}{c}2 \\
(<1-5)^{\mathrm{b}}\end{array}$ & $\begin{array}{c}30.7 \\
(15-87)^{\mathrm{a}}\end{array}$ & $\begin{array}{c}3.7 \\
(<2-12)^{\mathrm{a}}\end{array}$ & $\begin{array}{c}109 \\
(18-230)^{\mathrm{a}}\end{array}$ & $\begin{array}{c}0.011 \\
(0.010-0.012)^{\mathrm{b}, \mathrm{c}}\end{array}$ \\
\hline $\mathrm{H}-04$ & $\begin{array}{c}0.01(0.2)^{\mathrm{a}} \mathrm{mgd} \\
40(800) \mathrm{m}^{3} / \mathrm{d}\end{array}$ & $\begin{array}{c}6.8 \\
(6.1-8)^{\mathrm{b}}\end{array}$ & $<^{\mathrm{b}}$ & $\begin{array}{c}\text { Not } \\
\text { sampled }\end{array}$ & $\begin{array}{c}23.8 \\
(9-61)^{\mathrm{a}}\end{array}$ & $\begin{array}{c}236 \\
(61-799)^{\mathrm{a}}\end{array}$ & $\begin{array}{c}0.004 \\
(0.002-0.005)^{\mathrm{b}, \mathrm{c}}\end{array}$ \\
\hline
\end{tabular}

Sources: a Specht 2004

b Discharge Monitoring Report data for January 2003 - April 2004.

c Based on only two data points

Table 2. Results of June Sampling at Outfall H-02

\begin{tabular}{|l|c|c|l|c|c|}
\hline Constituent, units & $</>$ & Result & Constituent, units & $</>$ & Result \\
\hline Conductivity & & 66 & $\mathrm{Ca}, \mu \mathrm{g} / \mathrm{l}$ & & 1475 \\
\hline $\mathrm{pH}$ & & 7.12 & $\mathrm{Cr}, \mu \mathrm{g} / \mathrm{l}$ & & 2.095 \\
\hline $\mathrm{NH} 4, \mathrm{mg} / \mathrm{l}$ & $<$ & 0.5 & $\mathrm{Mn}, \mu \mathrm{g} / \mathrm{l}$ & & 39.09 \\
\hline $\mathrm{NO}, \mathrm{mg} / \mathrm{l}$ & & 0.9 & $\mathrm{Co}, \mu \mathrm{g} / \mathrm{l}$ & & 0.526 \\
\hline $\mathrm{NO}, \mathrm{mg} / \mathrm{l}$ & $<$ & 1.0 & $\mathrm{Ni}, \mu \mathrm{g} / \mathrm{l}$ & & 1.979 \\
\hline $\mathrm{Cl}, \mathrm{mg} / \mathrm{l}$ & $<$ & 1.0 & $\mathrm{Cu}, \mu \mathrm{g} / \mathrm{l}$ & & 39.19 \\
\hline $\mathrm{PO} 4, \mathrm{mg} / \mathrm{l}$ & & 1.8 & $\mathrm{Zn}, \mu \mathrm{g} / \mathrm{l}$ & & 127.1 \\
\hline $\mathrm{SO} 4, \mathrm{mg} / \mathrm{l}$ & & 1.7 & $\mathrm{As}, \mu \mathrm{g} / \mathrm{l}$ & & 0.659 \\
\hline $\mathrm{Fe}, \mu \mathrm{g} / \mathrm{l}$ & & 499.9 & $\mathrm{Sr}, \mu \mathrm{g} / \mathrm{l}$ & & 7.726 \\
\hline $\mathrm{Li}, \mu \mathrm{g} / \mathrm{l}$ & & 1.629 & $\mathrm{Mo}, \mu \mathrm{g} / \mathrm{l}$ & & 0.801 \\
\hline $\mathrm{Be}, \mu \mathrm{g} / \mathrm{l}$ & & 0.102 & $\mathrm{Ag}, \mu \mathrm{g} / \mathrm{l}$ & & 0.001 \\
\hline $\mathrm{B}, \mu \mathrm{g} / \mathrm{l}$ & & 8.101 & $\mathrm{Cd}, \mu \mathrm{g} / \mathrm{l}$ & & 0.580 \\
\hline $\mathrm{Na}, \mu \mathrm{g} / \mathrm{l}$ & & 8832 & $\mathrm{Sb}, \mu \mathrm{g} / \mathrm{l}$ & & 0.312 \\
\hline $\mathrm{Mg}, \mu \mathrm{g} / \mathrm{l}$ & & 396.8 & $\mathrm{Ba}, \mu \mathrm{g} / \mathrm{l}$ & & 10.03 \\
\hline $\mathrm{Al}, \mu \mathrm{g} / \mathrm{l}$ & & 970.1 & $\mathrm{Au}, \mu \mathrm{g} / \mathrm{l}$ & & -7.073 \\
\hline $\mathrm{P}, \mu \mathrm{g} / \mathrm{l}$ & & 378.5 & $\mathrm{~Pb}, \mu \mathrm{g} / \mathrm{l}$ & & 4.921 \\
\hline $\mathrm{K}, \mu \mathrm{g} / \mathrm{l}$ & & 1160 & & & \\
\hline
\end{tabular}


Table 3. Interim NPDES Limits for Outfalls H-02 and H-04

\begin{tabular}{|c|c|c|}
\hline \multirow[b]{2}{*}{ Parameter } & \multicolumn{2}{|c|}{ Concentration } \\
\hline & Monthly Average & Daily Maximum \\
\hline \multicolumn{3}{|l|}{ Outfall H-02 } \\
\hline Flow & MR mgd & MR mgd \\
\hline $\mathrm{pH}(\mathrm{su})$ & & 4.8 to 8.5 \\
\hline Copper, total (mg/l) & MR & MR \\
\hline Lead, total (mg/l) & MR & MR \\
\hline Mercury, total $(\mu \mathrm{g} / \mathrm{l})$ & MR & MR \\
\hline Zinc, total (mg/l) & MR & MR \\
\hline \multicolumn{3}{|l|}{ Outfall H-04 } \\
\hline Flow & MR mgd & MR mgd \\
\hline $\mathrm{pH}(\mathrm{su})$ & & 4.8 to 8.5 \\
\hline Lead, total (mg/l) & MR & MR \\
\hline Mercury, total $(\mu \mathrm{g} / \mathrm{l})$ & MR & MR \\
\hline Zinc, total (mg/l) & - & MR \\
\hline TSS (mg/l) & 20 & 40 \\
\hline
\end{tabular}

MR - Monitor and Report

Table 4. Final NPDES Limits for Outfalls $\mathrm{H}-02$ and H-04

\begin{tabular}{|l|l|l|}
\hline & Concentration & Daily Maximum \\
\hline Parameter & Monthly Average & \\
\hline Outfall H-02 & & MR mgd \\
\hline Flow & MR mgd & 4.8 to 8.5 \\
\hline $\mathrm{pH}(\mathrm{su})$ & & 0.009 \\
\hline Copper, total $(\mathrm{mg} / \mathrm{l})$ & 0.007 & 0.02 \\
\hline Lead, total $(\mathrm{mg} / \mathrm{l})$ & 0.001 & 0.07 \\
\hline Mercury, total $(\mu \mathrm{g} / \mathrm{l})$ & 0.051 & 0.10 \\
\hline Zinc, total $(\mathrm{mg} / \mathrm{l})$ & & \\
\hline Outfall H-04 & & MR mgd \\
\hline Flow & MR mgd & 4.8 to 8.5 \\
\hline pH (su) & & 0.02 \\
\hline Lead, total $(\mathrm{mg} / \mathrm{l})$ & 0.00083 & 0.07 \\
\hline Mercury, total $(\mu \mathrm{g} / \mathrm{l})$ & 0.051 & 0.10 \\
\hline Zinc, total $(\mathrm{mg} / \mathrm{l})$ & - & 40 \\
\hline TSS $(\mathrm{mg} / \mathrm{l})$ & 20 & \\
\hline
\end{tabular}

MR - Monitor and Report 


\section{Treatment objectives}

Constituents exceeding NPDES permit limits must be reduced to within those NPDES permit limits.

Based on recent data, the concentrations of copper, lead and zinc in the H-02 effluent (Table 1) all exceed the Final Limits specified in the NPDES Permit (Table 4). In the H-04 effluent, the mean concentrations of lead and zinc (Table 1) exceed the Final Limits specified in the NPDES Permit (Table 4). Constituents above the NPDES limit and the required removal rates to meet the NPDES limits are shown in Table 5.

Table 5. Constituents Above NPDES Limits and Required Removal Rates

\begin{tabular}{|c|c|c|c|}
\hline Constituent & NPDES Limit & $\begin{array}{c}\text { Existing } \\
\text { Concentration }\end{array}$ & $\begin{array}{c}\text { Removal Rate } \\
\text { Required }\end{array}$ \\
\hline \multicolumn{4}{|l|}{ H-02 } \\
\hline Copper, total & $\begin{array}{l}7 \mu \mathrm{g} / \mathrm{l} \text { avg. } \\
9 \mu \mathrm{g} / \mathrm{l} \text { max. }\end{array}$ & $\begin{array}{l}30.7 \mu \mathrm{g} / \mathrm{l} \text { avg. } \\
87 \mu \mathrm{l} / \mathrm{max} .\end{array}$ & $\begin{array}{l}77 \% \\
90 \% \\
\end{array}$ \\
\hline Lead, total & $\begin{array}{c}1 \mu \mathrm{g} / \mathrm{l} \text { avg. } \\
20 \mu \mathrm{g} / \mathrm{l} \text { max. }\end{array}$ & $\begin{array}{l}3.7 \mu \mathrm{g} / \mathrm{l} \text { avg. } \\
12 \mu \mathrm{g} / \mathrm{l} \text { max. }\end{array}$ & $\begin{array}{c}73 \% \\
0 \% \\
\end{array}$ \\
\hline Zinc, total & $100 \mu \mathrm{g} / \mathrm{l} \max$. & $230 \mu \mathrm{g} / \mathrm{l} \max$ & $57 \%$ \\
\hline \multicolumn{4}{|l|}{ H-04 } \\
\hline Lead, total & $\begin{array}{c}0.83 \mu \mathrm{g} / \mathrm{l} \text { avg. } \\
20 \mu \mathrm{g} / \mathrm{l} \text { max. }\end{array}$ & $\begin{array}{c}23.8 \mu \mathrm{g} / \mathrm{l} \text { avg. } \\
61 \mu \mathrm{g} / \mathrm{l} \text { max. }\end{array}$ & $\begin{array}{l}97 \% \\
67 \% \\
\end{array}$ \\
\hline Zinc, total & $100 \mu \mathrm{g} / \mathrm{l} \max$. & $799 \mu \mathrm{g} / \mathrm{l}$ max. & $87 \%$ \\
\hline
\end{tabular}

\section{TREATMENT WETLAND SYSTEM DESCRIPTION}

\section{General Information}

Constructed wetlands can treat contaminants such as total suspended solids (TSS), biochemical oxygen demand (BOD), nutrients (nitrogen and phosphorus), organic compounds, and inorganic constituents (such as metals) to meet regulatory targets. The two main types of constructed wetlands are surface flow (SF) and subsurface flow (SSF). A SF wetland typically consists of a basin or channels with a barrier layer to prevent seepage, soil to support rooted vegetation, and relatively shallow water flowing through the system. The water flows primarily horizontally and above ground. The SRS A-01 constructed wetland is a good example of a SF wetland. The SSF wetland also consists of a basin or channel with a seepage barrier, but the bed is filled with porous media, such as rock and gravel. The media supports the vegetation root structure. SSF wetlands are designed to keep the water level below the top of the rock or gravel media. The flow path through the operational SSF systems in the U.S. is usually horizontal, but may be vertical (USEPA 1993b).

There are more than twice as many SF systems in the United States than SSF systems. In Europe SSF systems outnumber SF systems. In general, SF wetlands require more land to achieve the same pollution reduction as SSF wetlands, but are easier and cheaper to design and build (USEPA 1993a, ITRC 2003).

Constructed wetlands have many advantages compared to conventional treatment techniques. They:

- have significantly lower total lifetime costs and often lower capital costs than conventional treatment systems.

- tolerate fluctuations in flow and pollutant concentrations,

- are capable of treating multiple or mixed contaminants,

- provide flood protection, 
- have lower air and water emissions and secondary wastes,

- can be built to fit into the landscape,

- provide habitat for plants and wildlife,

- provide recreational and educational opportunities, and

- are environmentally friendly and are viewed favorably by the general public and regulators (USDA 1995, ITRC 2003).

There are some limitations to the use of constructed wetlands in treating wastewater:

- They generally require larger land areas than conventional wastewater treatment systems, so adequate land must be available.

- They may be relatively slow to provide treatment compared to more conventional treatment technologies.

- Performance may be less consistent than in conventional treatment; constructed wetlands depend on climate and, thus, may have reduced efficiencies during colder seasons.

- Surges in flow or pollutants may temporarily reduce treatment effectiveness.

- They require a base flow of water; they can tolerate temporary water level drawdowns, but not complete drying.

- They may provide breeding grounds for mosquitoes and other pests, though proper design can reduce this problem.

- Anaerobic conditions might produce disagreeable odors associated with natural biological functions, though proper design can reduce this problem.

- $\quad$ Long-term maintenance may be required.

- The biological components are sensitive to toxic chemicals.

- Contaminant accumulation must be monitored to maintain ecological health of the system (USDA 1995, ITRC 2003).

SF and SSF wetlands are discussed further below. Advantages and disadvantages or each are shown in Table 6.

\section{Surface-flow (SF) wetlands}

SF wetlands consist of shallow basins partially filled with soil, peat or any other media that will support plant roots. SF wetlands generally have a soil bottom, emergent vegetation, and a water surface above the substrate (Figure 2). The design may or may not include areas of open water in addition to the vegetated areas. SF wetlands are sometimes called free water surface wetlands or aerobic wetlands. The water moves slowly through the wetland above the substrate. The near-surface layer of water is aerobic while the deeper waters and the substrate are usually anaerobic (USDA 1995, ITRC 2003). The vegetation is usually cattails, reeds, sedges, and rushes (Hurtado 2004). Plants in these SF systems can tolerate continuously saturated soil conditions and the resulting anaerobic soils (USDA 1995, ITRC 2003). Figure 3 shows the elements of a SSF wetland system.

SF wetlands are densely vegetated and typically have water depths less than $1.3 \mathrm{ft}(0.4 \mathrm{~m})$ (Kadlec and Knight 1996). Typical hydraulic loading rates are between 0.3 and $2 \mathrm{in} /$ day $(0.7$ and $5.0 \mathrm{~cm} /$ day), which corresponds to a wetland of 18.7 to 131 acres per mgd of flow (2 to 14 ha per $1000 \mathrm{~m}^{3} /$ day of flow) (Kadlec and Knight 1996). Typical flow depths for SF systems are 0.3 to $2.0 \mathrm{ft}$ (0.09 to $0.6 \mathrm{~m}$ ) (Tchobanoglous and Burton 1991). 
Table 6. Advantages and Disadvantages of Surface Flow and Subsurface Flow Wetlands

\begin{tabular}{|c|c|}
\hline \multicolumn{2}{|c|}{ Surface Flow Wetland } \\
\hline Advantages & Disadvantages \\
\hline $\begin{array}{l}\text { Less expensive to construct (on a cost per acre } \\
\text { basis) and operate and simpler to design than } \\
\text { SSF wetlands and conventional treatment } \\
\text { methods. }\end{array}$ & $\begin{array}{l}\text { Lower rates of contaminant removal per unit of } \\
\text { land than SSF wetlands, thus they require more } \\
\text { land to achieve a particular level of treatment } \\
\text { than SSF wetlands. }\end{array}$ \\
\hline $\begin{array}{l}\text { Can be used for higher suspended solids } \\
\text { wastewaters. }\end{array}$ & $\begin{array}{l}\text { Requires more land than conventional } \\
\text { treatment methods. }\end{array}$ \\
\hline $\begin{array}{l}\text { More operating data in the United States than } \\
\text { for SSF wetlands. }\end{array}$ & $\begin{array}{l}\text { Risk of ecological or human exposure to } \\
\text { surface-flowing wastewater. }\end{array}$ \\
\hline Offer greater flow control than SSF wetlands & $\begin{array}{l}\text { May be slower to provide treatment than } \\
\text { conventional treatment }\end{array}$ \\
\hline Offer more diverse wildlife habitat. & $\begin{array}{l}\text { Odors and insects may be a problem due to the } \\
\text { free water surface. }\end{array}$ \\
\hline Provides habitat for plants and wildlife. & \\
\hline \multicolumn{2}{|c|}{ Subsurface Flow Wetland } \\
\hline Advantages & Disadvantages \\
\hline $\begin{array}{l}\text { Higher rates of contaminant removal per unit of } \\
\text { land than SF wetlands, thus they require less } \\
\text { land to achieve a particular level of treatment } \\
\text { than SF wetlands. }\end{array}$ & $\begin{array}{l}\text { Requires more land than conventional } \\
\text { treatment methods. }\end{array}$ \\
\hline $\begin{array}{l}\text { Lower total lifetime costs and capital costs than } \\
\text { conventional treatment systems. }\end{array}$ & $\begin{array}{l}\text { May be slower to provide treatment than } \\
\text { conventional treatment }\end{array}$ \\
\hline Less expensive to operate than SF systems. & $\begin{array}{l}\text { More expensive to construct than SF wetlands } \\
\text { on a cost per acre basis. }\end{array}$ \\
\hline $\begin{array}{l}\text { Minimal ecological risk due to absence of an } \\
\text { exposure pathway. }\end{array}$ & $\begin{array}{l}\text { Waters containing high suspended solids may } \\
\text { cause plugging. }\end{array}$ \\
\hline \multicolumn{2}{|l|}{$\begin{array}{l}\text { More accessible for maintenance because there } \\
\text { is no standing water. }\end{array}$} \\
\hline \multicolumn{2}{|l|}{$\begin{array}{l}\text { Odors and insects not a problem because the } \\
\text { water level is below the media surface. }\end{array}$} \\
\hline Provides habitat for plants and wildlife. & \\
\hline
\end{tabular}




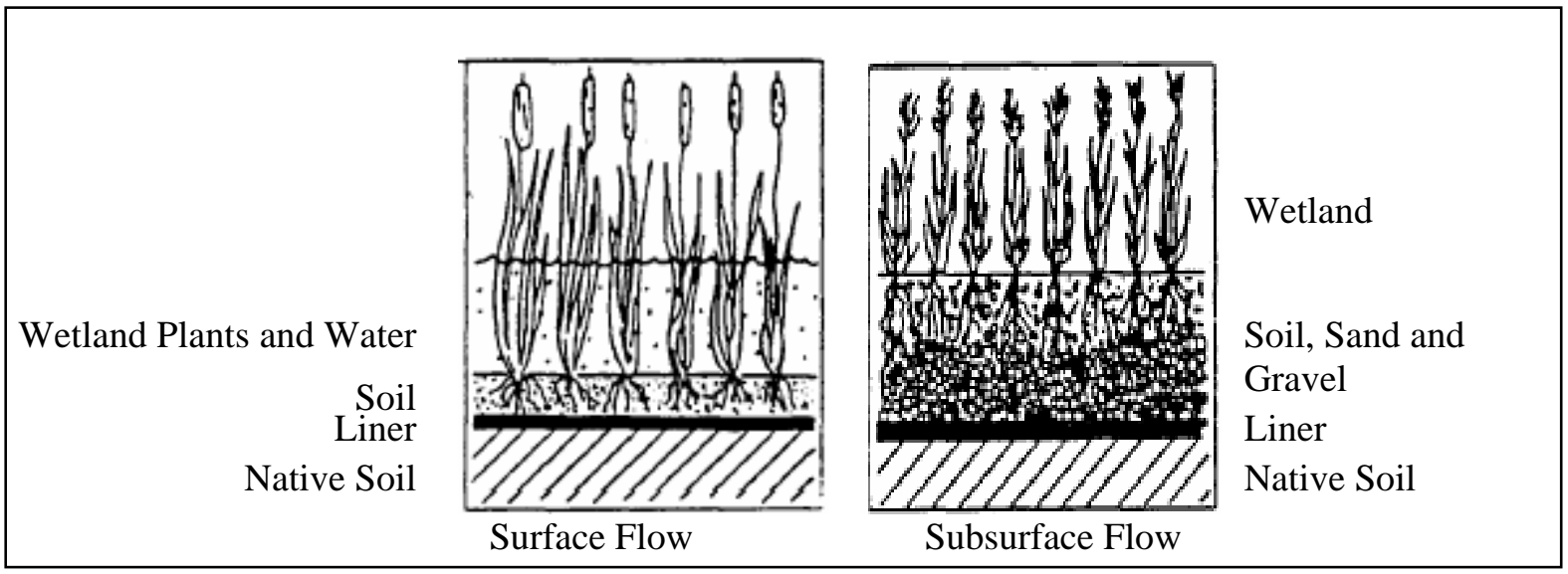

Source: USDA 1995

Figure 2. Surface Flow vs. Subsurface Flow Constructed Wetland

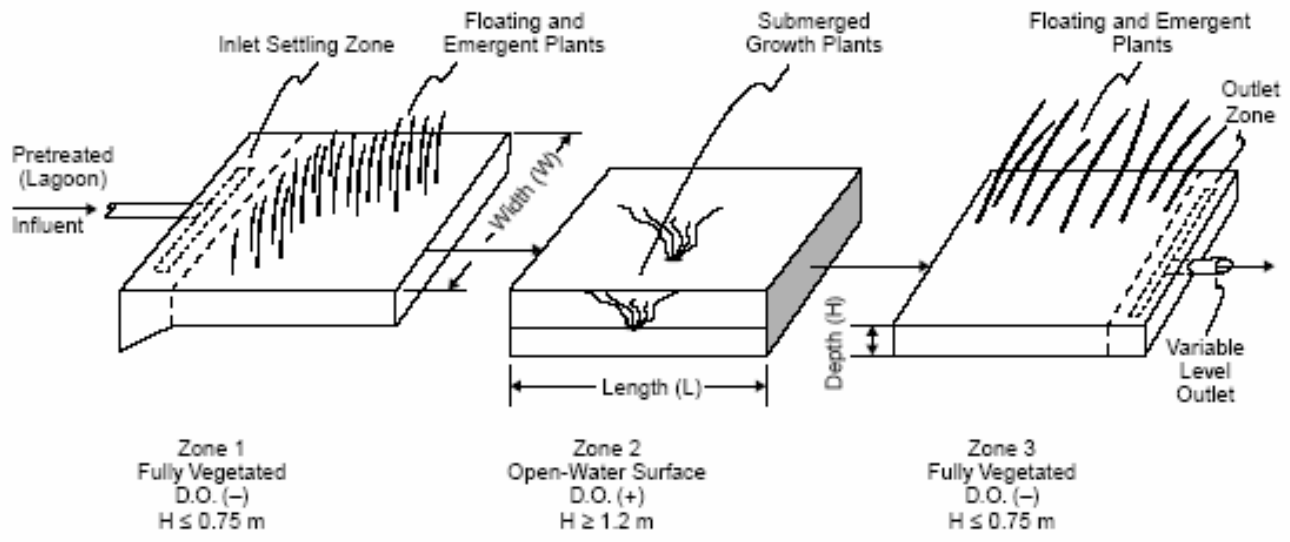

Source: USEPA 2000a

Figure 3. Elements of a SF Wetland System

SF wetlands are generally cheaper to construct (on a cost per acre basis) and are simpler to design than SSF wetlands. They are easy to construct, operate and maintain. They also provide more diverse wildlife habitat due to areas of free water surface. SF wetlands offer greater flow control than SSF wetlands (USDA, 1995, ITRC 2003). The main disadvantage of SF systems is that they generally require more land than SSF systems (Lorion 2001, USDA 1995).

For wastewaters containing contaminant metals, SF wetlands are generally used to collect water, provide aeration, and retain the water long enough that metals in the water can precipitate. The extensive water surface and slow flow in SF wetlands foster metal oxidation and hydrolysis. The compounds precipitate and are retained in the wetlands. The extent of metal removal depends on dissolved metal concentrations, dissolved oxygen content, $\mathrm{pH}$, retention time of the water in the wetland and other factors. For metals removal, SF wetlands are best used with water that contains net alkalinity to neutralize metal acidity and allow metals precipitation to continue (Skousen 2004). 


\section{Subsurface-flow wetlands (SSF)}

SSF wetlands are generally constructed with a porous material (e.g. soil, sand, or gravel) as a substrate for growth of rooted wetland plants (Figure 2) in addition to various microbes. SSF wetlands are also known as reed beds, rock-reed filters, gravel beds, and vegetated submerged beds (USDA 1995, ITRC 2003). They can also be known as anaerobic wetlands (Skousen 2004). SSF wetlands are designed so that water flows horizontally or vertically through the substrate and below the ground surface (USDA 1995, ITRC 2003). Distinct aerobic and anaerobic treatment zones become established, which improves wastewater treatment (Dusel and Pawlewski 2004). The emergent vegetation, mostly bulrush, reeds, and sometimes cattails, supplies oxygen to the substrate and allows biological growth to accumulate on its roots (Hurtado 2004). Bacteria and beneficial fungi live in the substrate as biofilm attached to the substrate particles (ITRC 2003). Flow is maintained by either a sloping bottom and/or an adjustable outlet structure which allows the water level to be lowered at the end of the bed, producing the pressure head required to overcome flow resistance through the substrate media. An adjustable outlet provides greater flexibility and control and is the recommended method (USEPA 1993b). Figure 4 shows the elements of a SSF wetland system. Figure 5 shows a typical cross section of a SSF wetland cell.

Bed depth for SSF wetlands is generally less than $2 \mathrm{ft}(0.6 \mathrm{~m})$ (Kadlec and Knight 1996). Typical flow depths vary from 1.6 to $2.6 \mathrm{ft}$ (0.49 to $0.79 \mathrm{~m}$ ) (Cooper et al. 1998). Typical hydraulic loading rates are between 0.8 - 8 in/day ( 2 and $20 \mathrm{~cm} /$ day), which corresponds to a wetland of 4.7 to 47 acres per mgd of flow (0.5 to 5 ha per $1000 \mathrm{~m}^{3}$ /day of flow) (Kadlec and Knight 1996).

SSF wetlands can be classified into two basic flow systems: horizontal flow and vertical flow. Horizontal flow systems are more common, therefore more operations data exist for horizontal flow wetlands than for vertical flow systems. Horizontal and vertical flow systems have similar contaminant removal mechanisms, but different hydraulics. In horizontal subsurface flow wetlands, the wastewater flows only through the substrate. SSF wetlands should have no continuous free surface water or the flow will shortcircuit, moving quickly across the surface of the wetland and resulting in incomplete treatment. Vertical systems are constructed so that water moves uniformly down or up through the substrate. Water is generally ponded on the surface to help maintain anaerobic conditions in the substrate and to provide hydraulic head to encourage flow. Vertical flow systems are more common in mining applications. Some vertical flow systems combine an organic substrate with the inorganic permeable media (ITRC 2003).

SSF wetlands support metal oxidation and hydrolysis in aerobic surface layers and chemical and microbial reduction reactions in the subsurface layers to precipitate metals. The water infiltrates through the subsurface sediment, becoming anaerobic due to high biological oxygen demand. Several treatment mechanisms are enhanced in the anaerobic conditions, including formation and precipitation of metal sulfides and metal exchange and complexation reactions (Skousen 2004).

The SSF type of wetland is thought to have several advantages over the SF type. SSF wetlands demonstrate higher rates of contaminant removal per unit of land than SF wetlands (Lorion 2001, USDA 1995). The substrate provides more surface area for bacterial biofilm growth than a SF wetland, resulting in increased treatment effectiveness, which may translate to a smaller wetland (USDA 1995, ITRC 2003, USEPA 2000b). If the water surface is maintained below the media surface there is little risk of odors, lack of mosquitoes and other insect vectors, and minimal risk of public or animal exposure or contact with the water, (USEPA 1993b, Lorion 2001). In several locations, SSF wetlands are operating in parks (USDA 1995). Many industrial waste streams containing hazardous substances can be treated in SSF wetlands with minimal ecological risk due to absence of an exposure pathway. SSF wetlands are better suited for cold weather operation than the SF wetlands because they are more insulated by the earth and accumulated plant debris on the surface of the SSF bed (Lorion 2001, ITRC 2003). Also, SSF wetlands are more accessible for maintenance because there is no standing water (ITRC 2003). However, SSF 
wetlands are best suited to wastewaters with relatively low solids concentrations to prevent clogging of the substrate (USDA 1995).

Hundreds of horizontal SSF wetlands operate dependably in Europe. SSF systems are preferred for their simple technology and reliable operating conditions (Kuschk et al. 2003). About 40 percent of the operational SSF systems in the U.S. use only bulrushes (Scirpus) for vegetation. Common reed (Phragmites) is widely used in European systems (USEPA 1993b, USDA 1995). A number of systems in the Gulf States have used flowering plants for aesthetic reasons (USEPA 1993b).

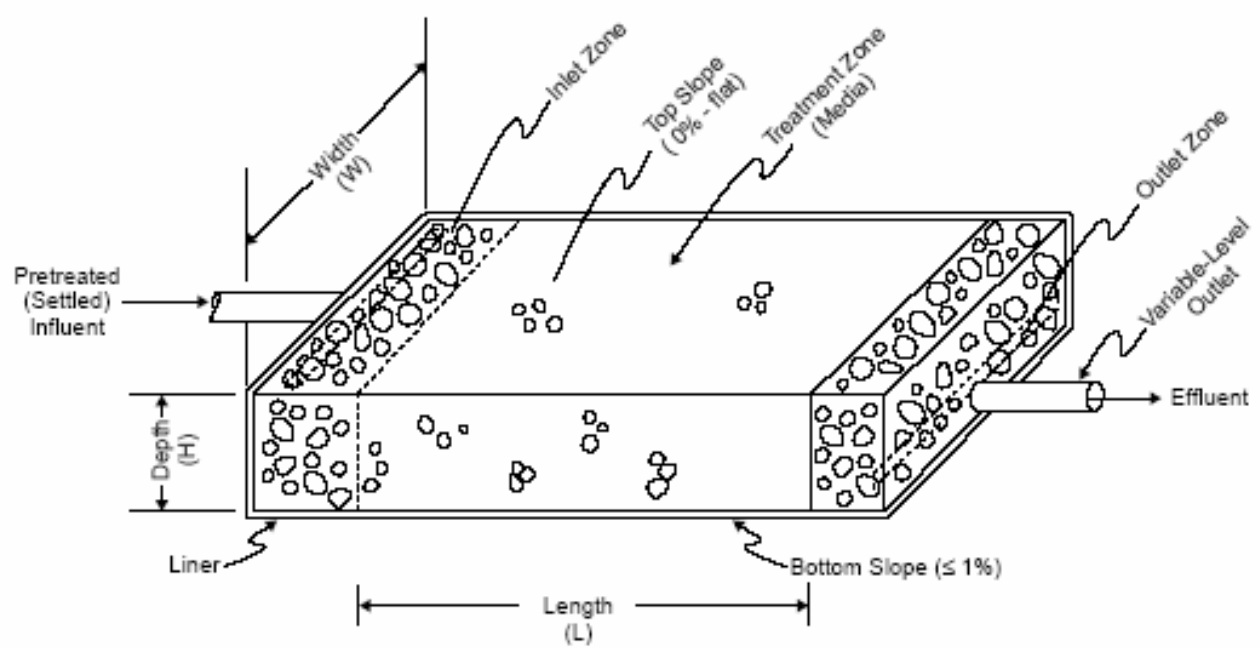

Source: USEPA 2000a

Figure 4. Elements of a SSF Wetland System

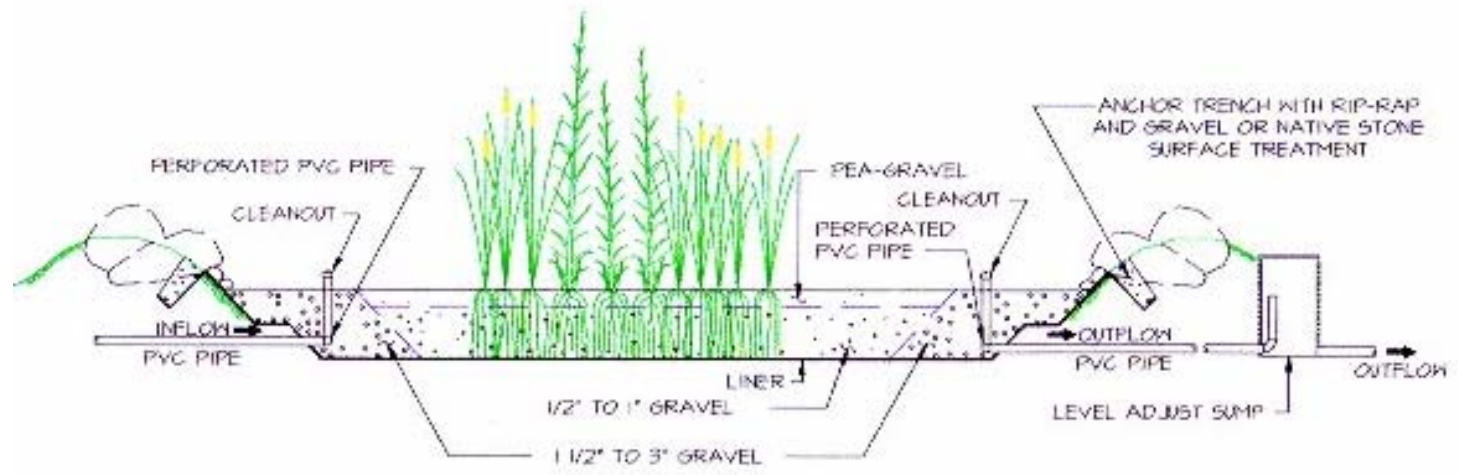

Source: NAHB 2004

Figure 5. Typical Cross-Section of a SSF Wetland Cell

\section{TREATMENT MECHANISMS AND PERFORMANCE}

Heavy metals are common environmental pollutants. Metal contamination of soils and waters has a severe impact on the environment and human health. Industrial and mining wastes are major sources of heavy metal environmental pollution (ITRC 2003). Heavy metals also can be found in municipal 
wastewater, even in the absence of major industrial input. The treatment goal is to remove the metals from the larger environment and from the food chain, especially in rivers and oceans. Constructed wetlands can accomplish the same level of removal at lower labor and energy costs than conventional wastewater treatment processes (USEPA 1988).

\section{General Removal Mechanisms}

A wetland is composed of water, substrate, plants, plant litter, invertebrates (mostly insect larvae and worms), and microorganisms (most importantly bacteria). Processes controlling contaminant retention in a constructed wetland sediment may be abiotic (physical and chemical) or biotic (microbial and phytological (i.e. botanical)) and are often interrelated (USDA 1995 and ITRC 2003).

The primary abiotic processes that are responsible for removing wastewater contaminants in a constructed wetland include the following:

- $\quad$ settling \& sedimentation - which achieve efficient removal of particulate matter and suspended solids

- sorption - including adsorption and absorption, the chemical process occurring on the surfaces of plants, substrate, sediment, and litter that results in short-term retention or long-term immobilization of contaminants

- chemical oxidation/reduction/precipitation - conversion of metals in the influent stream, through contact of the water with the substrate and litter, to an insoluble solid form that settles out, an effective means for immobilizing toxic metals in the wetland

- photodegradation/oxidation - degradation/oxidation of compounds in the presence of sunlight

- volatilization - which occurs when compounds with significant vapor pressures partition to the gaseous state (USDA 1995, ITRC 2003).

Biotic processes like biodegradation and plant uptake are also responsible for contaminant removal, in addition to the abiotic processes. Some microbial and phytological processes taking place in a wetland are given below:

- $\quad$ aerobic/anaerobic biodegradation - metabolic processes of microorganisms, which play a significant role in removing organic compounds in wetlands

- phytoaccumulation - uptake and accumulation of inorganic elements in plants

- phytostabilization - the ability to sequester inorganic compounds in plant roots

- phytodegradation - plant-produced enzymes break down the organic and inorganic contaminants that enter into the plant during transpiration

- rhizodegradation - plants provide exudates that enhance microbial degradation of organic compounds

- phytovolatilization/evapotranspiration - uptake and transpiration of volatile compounds through the leaves (ITRC 2003).

Some of these processes that can treat inorganic pollutants, such as metals, are shown in Figure 6.

The pollutant-transforming chemical reactions generally occur in the wetland water, detritus, and rooted soil zones as a result of the diverse microbial populations and high microbial activity that occurs in these layers. Flowing water contacts the microbes attached to the submerged substrate, providing opportunity for the microbes to remove the contaminants and use them as a nutrient source (ITRC 2003). In the case of SF wetlands these substrates are the submerged parts of the vegetation, the plant litter, and the benthic soil layer. In SSF wetlands the submerged substrate includes the plant roots and the surfaces of the media (gravel and soil) themselves. Because the media surface area in a SSF wetland exceeds the available substrate in a SF wetland, the microbial reaction rates in a SSF wetland can be higher for most 
contaminants. Thus a SSF wetland can be smaller than a SF wetland for the same flow rate (USEPA 2000b).

The transition from aerobic to anaerobic zones in the detritus, sediment, and soil layers promotes microbial diversity. Both zones support a unique and diverse community of microorganisms. Plants and microbes have a complex symbiotic relationship, often benefiting each other by exchanging nutrients or exudates or by other mechanisms (ITRC 2003).

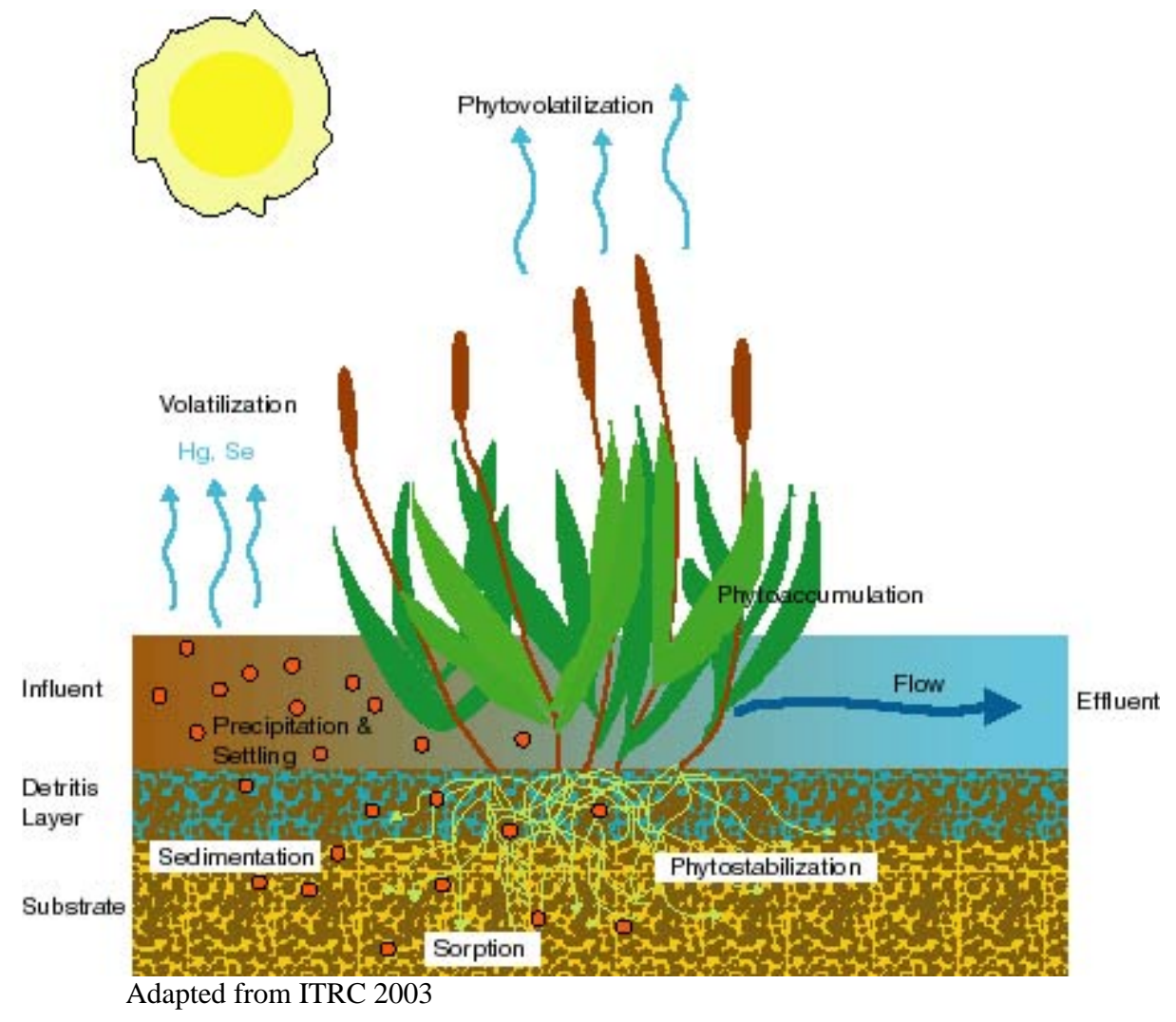

Figure 6. Mechanisms Treating Inorganic Compounds in Wetland Treatment Systems

\section{Metal Removal Mechanisms}

Metal removal processes occurring in wetlands involve a series of mechanisms (see Figure 7):

- filtration of solids - suspended solids, including adsorbed metals, are easily filtered and retained in wetlands

- $\quad$ sorption onto organic matter - several metals (e.g., copper, uranium and nickel) have a high affinity to bind to organic matter

- oxidation and hydrolysis - generally the main processes responsible for removal of aluminum, iron, and manganese

- formation of carbonates - which play an important role in the initial trapping of metals such as copper, manganese and nickel

- formation of insoluble sulfides - metals such as silver, cadmium, mercury, arsenic, copper, lead and zinc form highly insoluble sulfide compounds

- binding to iron and manganese oxides - which has been effective for arsenic, copper, iron, manganese, nickel, cobalt, lead, uranium, and zinc 
- reduction to nonmobile forms by bacterial activity - effective for chromium, copper, selenium and uranium

- biological methylation and volatilization of mercury - the methylation creating additional environmental problems (ITRC 2003)

- uptake by plants (e.g. algae) and bacteria (Kadlec and Knight 1996).

Most of these are discussed in further detail below.

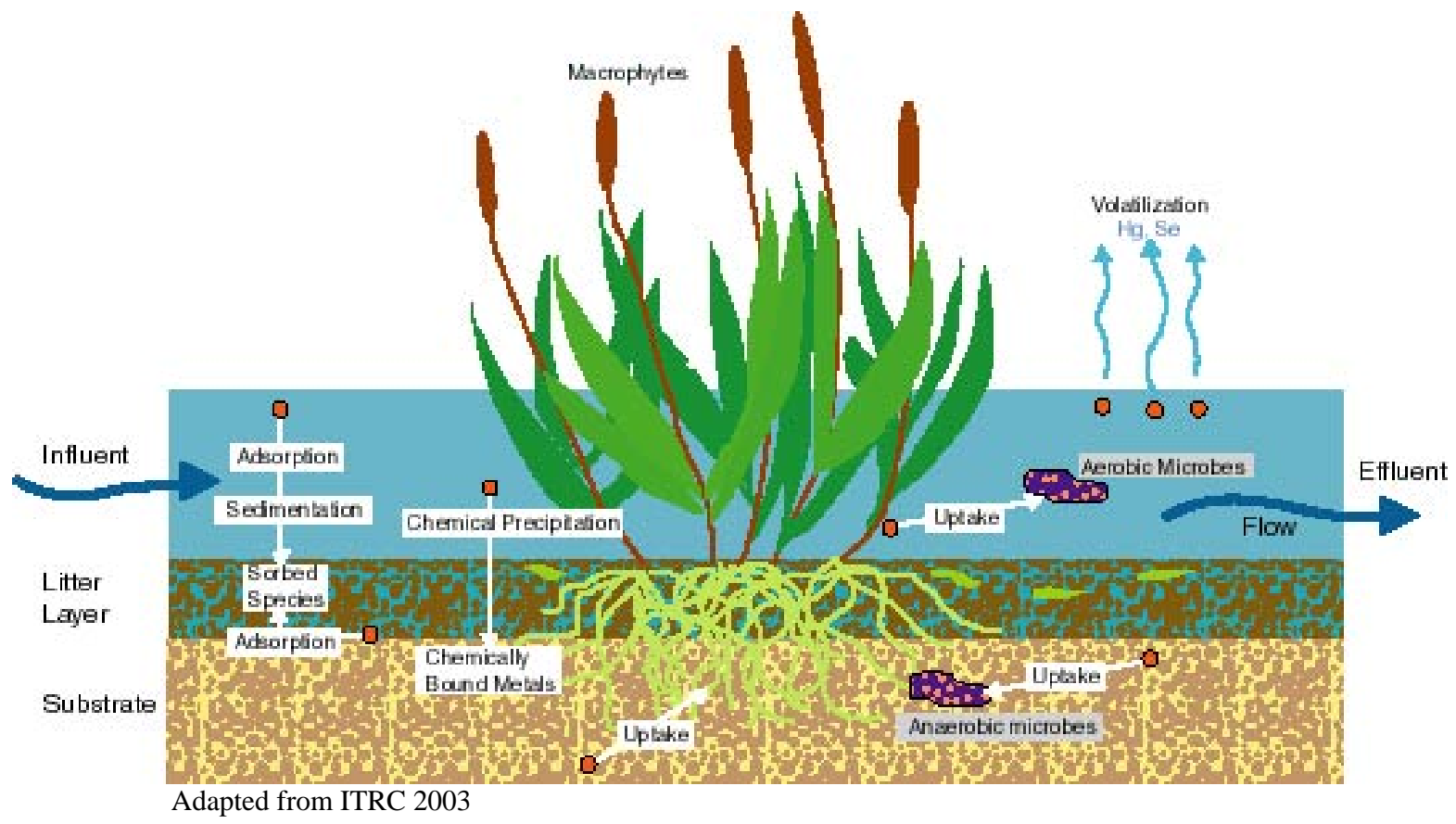

Figure 7. Mechanisms for Metals Removal in Wetlands

\section{Sorption of Metals onto Organic Matter}

Sorption, which includes adsorption and precipitation reactions, is the transfer of ions from the solution phase (water) to the solid phase (soil). In the organic substrate, adsorption (the attachment of ions to soil particles) seems to be the dominant mechanism for metals removal (Fitch and Burken 2004). Kadlec and Keoleian (1986) and Drever (1988) have documented that several metals, including copper, uranium and nickel, easily bind to organic matter, which is plentiful in wetland systems, especially in the detritus layer. The interactions involve the carboxyl and phenolic hydroxyl groups from organic matter, such as humic acid (Tipping and Hurley 1992), resulting in formation of stable complexes. Constructed wetlands may be designed to mimic the organic matter loading of natural wetlands by using an organic substrate such as peat to foster these reactions. But over time the adsorbed material may transform to metal sulfides (Fitch and Burken 2004). Also, organic matter can biodegrade and eventually release adsorbed metals (ITRC 2003). Boyle (1965) and Berner (1980) identified alternatives to prevent this release of metals, including formation of colloidal complexes and insoluble sulfides (ITRC 2003).

\section{Oxidation and Hydrolysis of Metals}

Aluminum, iron, and manganese can form insoluble compounds - oxides, oxyhydroxides, and hydroxides - via hydrolysis and/or oxidation (Karathanasis and Thompson 1995). Oxidation and hydrolysis are generally the main removal mechanisms for these three metals (ITRC 2003). Copper can also be removed from solution in this manner (Lehman et al. 2002). 


\section{Formation of Metal Carbonates}

Metals may form carbonates in the presence of high ambient bicarbonate concentrations. Carbonate formation can take place if limestone occurs in the flow path or with extensive bacterial production of bicarbonate alkalinity in the sediments. Carbonates can be important in initially capturing metals. Carbonate compounds are not as stable as sulfides, but may be transformed to more stable forms following the initial formation (ITRC 2003). Considerable quantities of copper and manganese carbonates have accumulated in some natural wetlands (Sobolewski 1999).

\section{Sulfate reduction and Formation of Insoluble Metal Sulfides}

Anaerobic conditions in wetlands promote the growth of sulfate-reducing bacteria, which generate hydrogen sulfide. Most transition metals react with hydrogen sulfide to form highly insoluble sulfides (Stumm and Morgan 1981). The organic-rich detritus of wetlands increases sulfate reduction. Silver, cadmium, mercury, arsenic, copper, lead and zinc form highly insoluble sulfide compounds in contact with even low concentrations of hydrogen sulfide (ITRC 2003).

\section{Binding of Metals to Iron and Manganese Oxides}

Iron and manganese will precipitate as oxides, oxyhydroxides, or hydroxides in an oxidizing environment, such as at the wetland surface. Metals may bind with the iron and manganese oxides (Stumm and Morgan 1981; Drever 1988) via adsorption or co-precipitation processes. These redox sensitive oxides may redissolve following changes in oxygen concentration (ITRC 2003). However, the copper, iron, manganese, nickel, cobalt, lead, uranium, and zinc that were bound to iron oxides in Northern Australian wetlands have shown no sign of dissolution from the wetland (Noller et al. 1994, Eapaea et al. 1995). A natural wetland in North Wales, England effectively retained arsenic, cobalt, nickel and zinc in association with iron oxides (Horsnail et al. 1969). Arsenic and zinc were reported to be bound to iron plaques at the surface of plant roots (Otte at al. 1995).

\section{Reduction of Metals to Nonmobile Forms by Bacterial Activity} Some metals (chromium, copper, selenium and uranium) can be reduced to immobile (e.g., metallic) forms by bacterial activity controlled by factors such as Eh-pH and sulfide concentrations in some wetlands (Sobolewski 1999). Copper was immobilized in slightly acidic wetlands (Boyle 1977), selenium was immobilized in natural wetlands where its soluble oxyanion was reduced to elemental, insoluble selenium (Oremland 1994), and chromium and uranium were immobilized when reduced through processes catalyzed by microorganisms (Fude et al. 1994) or by hydrogen sulfide (ITRC 2003).

\section{Biological Methylation and Volatilization of Mercury}

Mercury acts differently from other metals in wetland environments. In nature, mercury (Hg) exists in three principal forms: elemental mercury $[\mathrm{Hg}(0)]$, mercuric mercury [Hg(II)], and methyl mercury (Me$\mathrm{Hg}$ ). Under anaerobic sediment conditions in wetlands, mercuric ions are biomethylated by anaerobic microorganisms to methyl (mono- and dimethyl) mercury. Methyl mercury is a serious problem in aquatic ecosystems because it is highly toxic and readily biomagnifies in the food chain, thereby creating additional environmental problems. As a result, wetlands are generally not recommended for treating elevated levels of mercury unless pilot studies can demonstrate effective removal of mercury with limited methyl mercury production (ITRC 2003).

\section{Treatment Efficiency for Metals}

Metal removal rates can be high, but also can vary greatly depending upon the influent concentrations and the mass loading rate (Kadlec and Knight 1996). Table 7 summarizes the metal removal mechanisms discussed above and the removal efficiencies actually achieved for a number of existing treatment wetlands. Additional data on SSF wetland removal rates for the three metals of concern for outfalls H-02 and H-04 — copper, lead and zinc — are shown in Table 8. 
Table 7. Examples of Metals Removal in Wetland Treatment Systems

\begin{tabular}{|c|c|c|c|c|}
\hline Metal & Removal mechanism & Removal \% & Case study & References \\
\hline \multirow[t]{4}{*}{$\mathrm{Cd}$} & \multirow{4}{*}{$\begin{array}{ll}\text { - } & \text { Formation of } \\
\text { insoluble sulfides } \\
\text { - } & \text { Filtration of solids } \\
\text { and colloids }\end{array}$} & 98.7 & $\begin{array}{l}\text { Constructed meadow/marsh/pond, } \\
\text { Brookhaven, NY }\end{array}$ & Hendrey et al. 1979 \\
\hline & & 75 & Bulrushes in gravel & \multirow[t]{2}{*}{ Sinicrope et al. 1992} \\
\hline & & 79 & SSF wetlands & \\
\hline & & 99.7 & SF cattail & Noller et al. 1994 \\
\hline \multirow[t]{5}{*}{$\mathrm{Cr}$} & \multirow{5}{*}{$\begin{array}{l}\text { - } \\
\text { Reduction to } \\
\text { nonmobile form by } \\
\text { bacterial activity }\end{array}$} & 87.5 & $\begin{array}{l}\text { Constructed meadow/marsh/pond, } \\
\text { Brookhaven, NY }\end{array}$ & Hendrey et al. 1979 \\
\hline & & 40 & $\begin{array}{l}\text { Freshwater marsh receiving urban storm } \\
\text { water, Orlando, FL }\end{array}$ & Schiffer 1989 \\
\hline & & 84 & Bulrushes in gravel & \multirow[t]{2}{*}{ Sinicrope et al. 1992} \\
\hline & & 68 & SSF wetland & \\
\hline & & $>65$ & $\begin{array}{l}\text { SRS A-01: retention basin, bulrush SF } \\
\text { Cells, hydrosoils amended w/ gypsum }\end{array}$ & $\begin{array}{l}\text { Nelson et al. } 2002 \\
\text { Gladden et al. } 2003\end{array}$ \\
\hline \multirow[t]{6}{*}{$\mathrm{Cu}$} & \multirow{6}{*}{$\begin{array}{ll}\text { - } & \text { Sorption onto } \\
& \text { organic matter } \\
\text { - } & \text { Formation of } \\
\text { insoluble sulfides } \\
\text { - } & \text { Binding to iron and } \\
\text { manganese oxides } \\
\text { - } \\
\text { Reduction to } \\
\text { nonmobile form by } \\
\text { bacterial activity }\end{array}$} & 96 & $\begin{array}{l}\text { Constructed meadow/marsh/pond, } \\
\text { Brookhaven, NY }\end{array}$ & Hendrey et al. 1979 \\
\hline & & 87.5 & $\begin{array}{l}\text { Freshwater marsh receiving urban storm } \\
\text { water, Orlando, FL }\end{array}$ & Schiffer 1989 \\
\hline & & 70.1 & $\begin{array}{l}\text { Carolina bay receiving municipal } \\
\text { effluent, Myrtle Beach, SC }\end{array}$ & CH2M Hill 1992 \\
\hline & & 88 & SSF Wetland & \multirow[t]{2}{*}{ Sinicrope et al. 1992} \\
\hline & & 36 & Typha SF & \\
\hline & & $78-83$ & $\begin{array}{l}\text { SRS A-01: retention basin, bulrush SF } \\
\text { Cells, hydrosoils amended w/ gypsum }\end{array}$ & Knox et al. 2004 \\
\hline \multirow[t]{5}{*}{$\mathrm{Fe}$} & \multirow{5}{*}{$\begin{array}{ll}\text { - } & \text { Oxidation and } \\
\text { hydrolysis } \\
\text { - } & \text { Formation of } \\
& \text { carbonates } \\
\text { - } & \text { Binding to iron and } \\
\text { manganese oxides }\end{array}$} & 66.7 & $\begin{array}{l}\text { Constructed meadow/marsh/pond, } \\
\text { Brookhaven, NY }\end{array}$ & Hendrey et al. 1979 \\
\hline & & 58.2 & $\begin{array}{l}\text { Average for } 137 \text { acid mine drainage } \\
\text { constructed wetlands }\end{array}$ & Wieder 1989 \\
\hline & & 98 & $\begin{array}{l}\text { Acid mine drainage wetland, KY (Fabius } \\
\text { IMP1) }\end{array}$ & \multirow[t]{3}{*}{ Edwards 1993} \\
\hline & & 97 & $\begin{array}{l}\text { Acid mine drainage wetland, KY } \\
\text { (Widows Creek) }\end{array}$ & \\
\hline & & 9 & Natural wetland, TN & \\
\hline \multirow[t]{7}{*}{$\mathrm{Pb}$} & \multirow{7}{*}{$\begin{array}{l}\text { - Formation of } \\
\text { insoluble sulfides } \\
\text { - Filtration of solids } \\
\text { and colloids } \\
\text { - } \quad \text { Binding to iron and } \\
\text { manganese oxides }\end{array}$} & 83.3 & $\begin{array}{l}\text { Freshwater marsh receiving urban storm } \\
\text { water, Orlando, FL }\end{array}$ & Schiffer 1989 \\
\hline & & 26 & $\begin{array}{l}\text { Acid mine drainage wetland, KY } \\
\text { (Widows Creek) }\end{array}$ & Edwards 1993 \\
\hline & & 86 & Bulrushes in gravel & \multirow[t]{2}{*}{ Sinicrope et al. 1992} \\
\hline & & 80 & SSF Wetland & \\
\hline & & 98 & Typha SF & \multirow[t]{2}{*}{ Noller et al. 1994} \\
\hline & & 94 & Typha/Melaleuca SF & \\
\hline & & $77-87$ & $\begin{array}{l}\text { SRS A-01: retention basin, bulrush SF } \\
\text { Cells, hydrosoils amended w/ gypsum }\end{array}$ & Knox et al. 2004 \\
\hline
\end{tabular}


Table 7. Examples of Metals Removal in Wetland Treatment Systems (continued)

\begin{tabular}{|c|c|c|c|c|}
\hline Metal & Removal mechanism & Removal \% & Case study & References \\
\hline \multirow[t]{6}{*}{$\mathrm{Mn}$} & \multirow{6}{*}{$\begin{array}{ll}\text { - } & \text { Oxidation and } \\
\text { hydrolysis } \\
\text { - } & \text { Formation of } \\
\text { carbonates } \\
\text { - } \\
\text { Binding to iron and } \\
\text { manganese oxides }\end{array}$} & 43 & $\begin{array}{l}\text { Constructed meadow/marsh/pond, } \\
\text { Brookhaven, NY }\end{array}$ & Hendrey et al. 1979 \\
\hline & & 79 & $\begin{array}{l}\text { Acid mine drainage wetland, KY (Fabius } \\
\text { IMP1) }\end{array}$ & \multirow[t]{3}{*}{ Edwards 1993} \\
\hline & & 47 & $\begin{array}{l}\text { Acid mine drainage wetland, KY } \\
\text { (Widows Creek) }\end{array}$ & \\
\hline & & 40 & Natural wetland, TN & \\
\hline & & 98 & Typha SF & \multirow[t]{2}{*}{ Noller et al. 1994} \\
\hline & & 75 & Typha/Melaleuca SF & \\
\hline $\mathrm{Hg}$ & $\begin{array}{ll}\text { - } & \text { Sorption to } \\
\text { organics/silts } \\
\text { - } & \text { Possible } \\
\text { immobilization as } \\
\text { sulfides }\end{array}$ & $\begin{array}{l}5 \text { (whole } \\
\text { system) } \\
75 \text { (wetlands) }\end{array}$ & $\begin{array}{l}\text { SRS A-01: retention basin, bulrush SF } \\
\text { Cells, hydrosoils amended w/ gypsum }\end{array}$ & $\begin{array}{l}\text { Nelson et al. } 2002 \\
\text { Gladden et al. } 2003\end{array}$ \\
\hline \multirow[t]{7}{*}{$\mathrm{Ni}$} & \multirow{7}{*}{$\begin{array}{ll}\text { - } & \text { Sorption onto } \\
\text { organic matter } \\
\text { - } & \text { Formation of } \\
\text { carbonates } \\
\text { - } \\
\text { Binding to iron and } \\
\text { manganese oxides }\end{array}$} & 70.7 & $\begin{array}{l}\text { Constructed meadow/marsh/pond, } \\
\text { Brookhaven, NY }\end{array}$ & Hendrey et al. 1979 \\
\hline & & 25 & $\begin{array}{l}\text { Freshwater marsh receiving urban storm } \\
\text { water, Orlando, FL }\end{array}$ & Schiffer 1989 \\
\hline & & 46 & $\begin{array}{l}\text { Carolina bay receiving municipal } \\
\text { effluent, Myrtle Beach, SC }\end{array}$ & CH2M Hill 1992 \\
\hline & & 28 & $\begin{array}{l}\text { Carolina bay receiving municipal } \\
\text { effluent, Conway, SC }\end{array}$ & CH2M Hill 1991 \\
\hline & & 63 & Bulrushes in gravel & \multirow[t]{2}{*}{ Sinicrope et al. 1992} \\
\hline & & 49 & SSF Wetland & \\
\hline & & 90 & Typha/Melaleuca SF & Noller et al. 1994 \\
\hline $\mathrm{Ag}$ & $\begin{array}{ll}\text { - } & \text { Formation of } \\
\text { insoluble sulfides } \\
\text { - } & \text { Filtration of solids } \\
& \text { and colloids } \\
\end{array}$ & 75.9 & $\begin{array}{l}\text { Cypress-gum swamp receiving municipal } \\
\text { effluent, Conway, SC }\end{array}$ & CH2M Hill 1991 \\
\hline \multirow[t]{9}{*}{$\mathrm{Zn}$} & \multirow{9}{*}{$\begin{array}{ll}\text { - } & \text { Formation of } \\
\text { insoluble sulfides } \\
\text { - } & \text { Filtration of solids } \\
\text { and colloids } \\
\text { - } \\
\text { Binding to iron and } \\
\text { manganese oxides }\end{array}$} & 89.5 & $\begin{array}{l}\text { Constructed meadow/marsh/pond, } \\
\text { Brookhaven, NY }\end{array}$ & Hendrey et al. 1979 \\
\hline & & 66.7 & $\begin{array}{l}\text { Freshwater marsh receiving urban storm } \\
\text { water, Orlando, FL }\end{array}$ & Schiffer 1989 \\
\hline & & 73 & $\begin{array}{l}\text { Carolina bay receiving municipal } \\
\text { effluent, Myrtle Beach, SC }\end{array}$ & CH2M Hill 1992 \\
\hline & & 66 & $\begin{array}{l}\text { Carolina bay receiving municipal } \\
\text { effluent, Conway, SC }\end{array}$ & CH2M Hill 1991 \\
\hline & & 33 & $\begin{array}{l}\text { Acid mine drainage wetland, KY } \\
\text { (Widows Creek) }\end{array}$ & Edwards,1993 \\
\hline & & 79 & Bulrushes in gravel & \multirow[t]{2}{*}{ Sinicrope et al. 1992} \\
\hline & & 71 & SSF wetland & \\
\hline & & $96-98$ & Typha/Melaleuca SF & Noller et al. 1994 \\
\hline & & $54-68$ & $\begin{array}{l}\text { SRS A-01: retention basin, bulrush SF } \\
\text { Cells, hydrosoils amended w/ gypsum }\end{array}$ & Knox et al. 2004 \\
\hline
\end{tabular}


Table 8. Copper, Zinc and Lead Removal at Various SSF Wetlands

\begin{tabular}{|c|c|c|c|c|c|}
\hline Site & $\begin{array}{l}\text { Type of } \\
\text { wetland }\end{array}$ & Contaminant & $\begin{array}{c}\text { Influent } \\
\text { Concentration }\end{array}$ & $\begin{array}{c}\text { Effluent } \\
\text { Concentration }\end{array}$ & $\begin{array}{l}\text { Removal } \\
\text { Efficiency }\end{array}$ \\
\hline $\begin{array}{l}\text { Burleigh Tunnel, } \\
\text { Silver Plume, } \\
\text { Colorado }^{a}\end{array}$ & $\begin{array}{l}\text { Upflow SSF } \\
\text { Downflow } \\
\text { SSF }\end{array}$ & $\mathrm{Zn}$ & - & - & $\begin{array}{c}70-77 \% \\
>90 \%\end{array}$ \\
\hline $\begin{array}{l}\text { Bioreactor System } \\
\text { at West Fork } \\
\text { Mine, Missouri }^{\text {a }}\end{array}$ & $\begin{array}{l}\text { SSF followed } \\
\text { by aeration } \\
\text { pond }\end{array}$ & $\mathrm{Pb}$ & $0.4-0.6 \mathrm{mg} / \mathrm{l}$ & $\begin{array}{c}0.027-0.050 \\
\mathrm{mg} / \mathrm{l}\end{array}$ & $>91 \%$ \\
\hline Lab-scale system $^{\mathrm{b}}$ & SSF & $\begin{array}{l}\mathrm{Cu} \\
\mathrm{Pb} \\
\mathrm{Zn}\end{array}$ & $\begin{array}{l}1-20 \mathrm{mg} / \mathrm{l} \\
1-20 \mathrm{mg} / \mathrm{l} \\
1-20 \mathrm{mg} / \mathrm{l}\end{array}$ & - & $\begin{array}{l}82 \%-92 \% \\
76 \%-95 \% \\
83 \%-90 \%\end{array}$ \\
\hline Lab-scale system ${ }^{c}$ & $\begin{array}{l}\text { Vertical-flow } \\
\text { SSF }\end{array}$ & $\begin{array}{l}\mathrm{Pb} \\
\mathrm{Cu}\end{array}$ & $\begin{array}{l}1.30 \& 2.99 \mathrm{mg} / \mathrm{l} \\
0.99 \& 1.93 \mathrm{mg} / \mathrm{l}\end{array}$ & - & $\begin{array}{l}>96 \%-100 \% \\
>83 \%-<94 \%\end{array}$ \\
\hline $\begin{array}{l}\text { Tennessee Copper } \\
\text { Basin, Glenn } \\
\text { Springs Holdings, } \\
\text { Inc. }\end{array}$ & SSF & $\begin{array}{l}\mathrm{Cu} \\
\mathrm{Zn}\end{array}$ & $\begin{array}{c}0.33-0.43 \mathrm{mg} / \mathrm{l} \\
1-2 \mathrm{mg} / \mathrm{l}\end{array}$ & $\begin{array}{c}<0.025 \mathrm{mg} / \mathrm{l} \\
0.02 \mathrm{mg} / \mathrm{l}\end{array}$ & $\begin{array}{l}>92 \% \\
85 \%\end{array}$ \\
\hline $\mathrm{UK}^{\mathrm{e}}$ & SSF & $\begin{array}{l}\mathrm{Cu} \\
\mathrm{Cr} \\
\mathrm{Ni} \\
\mathrm{Zn}\end{array}$ & - & - & $\begin{array}{c}67.3 \\
69.8 \\
87 \\
60.6\end{array}$ \\
\hline $\begin{array}{lll}\text { Sources: } & \text { a } & \text { Lorion } \\
& \text { b } & \text { Mungu } \\
& \text { c } & \text { Scholz } \\
& \text { d } & \text { Faulkn } \\
& \text { e } & \text { Shutes }\end{array}$ & $\begin{array}{l}001 \\
\text { et al. } 1997 \\
003 \\
\text { and Miller } 2003 \\
\text { tal. } 2001\end{array}$ & & & & \\
\hline
\end{tabular}

In surface waters, copper is generally found as chelated compounds of $\mathrm{Cu}(\mathrm{II})$. Copper forms relatively insoluble complexes with hydroxides, sulfides and carbonates, which can be efficiently retained in wetland systems without biomagnifying significantly in the food chain. Peat and humic substances have a high affinity for copper. Some plants uptake copper in the roots, shoots and rhizomes (Kadlec and Knight 1996). The reduction of copper concentrations in wetlands has been studied at a variety of sites (Hendrey et al. 1979; DeLaune et al 1981; Giblin 1985; Best 1987; Feijtel et al. 1989; Schiffer 1989; CH2M Hill 1991 \& 1992; Sinicrope et al. 1992), as documented in Kadlec and Knight (1996) and ITRC (2003). Copper removal efficiency appears to correlate with inflow concentration up to $1,510 \mu \mathrm{g} / \mathrm{l}$, with highest removal rates seen in wetlands with high influent concentrations (Table 7 and Table 8) (Kadlec and Knight 1996). Recent studies at the SRS A-01 wetlands indicated that copper was very strongly bound to the sediments, with only $1 \%$ being easily remobilized and bioavailable (Knox et al. 2004). SF and SSF wetlands have proved successful at removing copper from wastewaters (Table 7 and Table 8).

Lead in surface waters is most often found in $\mathrm{Pb}(\mathrm{II})$ form. This divalent lead forms salts with sulfides, carbonates, sulfates and chlorophosphates, which can be removed by wetland systems via sedimentation. 
Lead solubility is generally less than $1 \mu \mathrm{g} / \mathrm{l}$ when $\mathrm{pH}$ is above 8.5, but is increasingly soluble with lower $\mathrm{pH}$ values and alkalinities. Some plants uptake lead, primarily in the roots (Kadlec and Knight 1996). Lead concentration reduction has been investigated at a variety of wetlands (DeLaune et al 1981; Giblin 1985; Feijtel et al. 1989; Schiffer 1989; CH2M Hill 1991 \& 1992; Sinicrope et al. 1992; Edwards 1993; Noller et al. 1994), as documented in Kadlec and Knight (1996) and ITRC (2003). At the SRS A-01 wetlands, recent studies showed lead was very strongly bound to the sediments, with only $5 \%$ being easily remobilized and bioavailable (Knox et al. 2004). Lead removal efficiency has been seen to increase with increasing inflow concentration, though negative removal efficiencies have been seen in natural wetlands receiving low lead concentrations (Kadlec and Knight 1996). SF and SSF wetlands have been used to efficiently remove lead from their influent (Table 7 and Table 8).

The effect of wetlands on zinc has been studied at a variety of sites (Hendrey et al. 1979; DeLaune et al 1981; Giblin 1985; Best 1987; Feijtel et al. 1989; Schiffer 1989; CH2M Hill 1991 \& 1992; Sinicrope et al. 1992; Edwards 1993; Noller et al. 1994), as documented in Kadlec and Knight (1996) and ITRC (2003). In surface water, zinc is present primarily as divalent Zn(II), which forms sulfides, hydrates, carbonates and organics. The sulfide form of zinc is highly insoluble and is responsible for much of the zinc removed in wetlands. At SRS, recent A- 01 wetland studies indicated only $2 \%$ of the zinc can be easily remobilized and become bioavailable (Knox et al. 2004). Some plants also uptake zinc, primarily in the roots. As with other metals, zinc concentration and mass removal efficiency appears to correlate with inflow concentration up to $2200 \mu \mathrm{g} / \mathrm{l}$ and $124.5 \mathrm{~kg} / \mathrm{ha} / \mathrm{yr}$ (111 lb/acre/yr) (Kadlec and Knight 1996). SSF wetlands have proved successful at removing zinc from wastewaters (Table 7 and Table 8).

Constructed wetlands have been and are being used for a variety of wastewaters containing metal contaminants, including municipal wastewater, metal mine drainage and hazardous waste landfill leachate. Constructed wetlands have been used for years in treating municipal wastewater to remove suspended solids, BOD, organic compounds, and nutrients (nitrogen and phosphorous), in addition to metals. Contaminant removal is accomplished through the natural physical, chemical, and biological processes occurring in the wetlands. In the last 20 years, most municipal constructed treatment wetlands have been used for polishing treated wastewater (tertiary treatment), but SSF and SF wetlands are now being effectively used for secondary treatment also, alone or in combination with other technologies. More than $80 \%$ of these treat less than a million gallons of wastewater per day (ITRC 2003). Typical influent concentrations and removal efficiencies for municipal wastewaters are shown in Table 9.

Contaminated water draining from abandoned mines adversely impacts more then 19,000 km (12,000 miles) of rivers and streams and over 730 square $\mathrm{km}$ (180,000 acres) of lakes and reservoirs nationwide (Kleinmann 2000). In the 1980s, natural wetlands receiving mine drainage were found to be capable of removing significant amounts of metals from the water (Eger et al. 1980; Weider and Lang 1982; Eger and Lapakko 1988). Based on these findings, both SSF and SF wetlands began to be constructed in the mid-1980s to treat various types of mine drainage. More than a thousand wetlands have been built to treat mine drainage. These have ranged in size from less than an acre to over a thousand acres (ITRC 2003). Typical influent concentrations and removal efficiencies are shown in Table 9.

The use of constructed wetland treatment technology to treat wastewater, such as leachate, from hazardous waste sites managed under the federal Comprehensive Environmental Response Compensation and Liability Act (CERCLA), Resource Conservation and Recovery Act (RCRA) and state programs is increasing. These waste sites often have consistent, high flow, low concentration wastewater streams. Hazardous waste contamination treatable by constructed wetlands includes biochemical oxygen demand, chemical oxygen demand, petroleum hydrocarbons, polycyclic aromatic hydrocarbons, volatile organic carbons, some semi-volatile compounds, suspended solids, nutrients, and metals (ITRC 2003). Typical influent concentrations and removal efficiencies for RCRA/CERCLA treatment wetlands in New York are shown in Table 9. 
Table 9. Typical Influent Concentrations and Removal Efficiencies for Three Types of Wastewaters

\begin{tabular}{|c|c|c|c|c|c|c|}
\hline \multirow[b]{2}{*}{ Pollutant } & \multicolumn{2}{|c|}{ Municipal Wastewater } & \multicolumn{2}{|c|}{ Metal Mine Drainage } & \multicolumn{2}{|c|}{$\begin{array}{c}\text { RCRA/CERCLA } \\
\text { Hazardous Waste Landfill } \\
\text { Leachate }\end{array}$} \\
\hline & $\begin{array}{c}\text { Influent } \\
\text { Concentration } \\
a\end{array}$ & $\begin{array}{l}\text { Removal } \\
\text { Efficiency } \\
\text { a }\end{array}$ & $\begin{array}{c}\text { Influent } \\
\text { Concentration } \\
\mathbf{b} \\
\text { (net acid } \\
\text { drainage) } \\
\end{array}$ & $\begin{array}{l}\text { Removal } \\
\text { Efficiency } \\
\mathbf{b}\end{array}$ & $\begin{array}{c}\text { Influent } \\
\text { Concentration }\end{array}$ & $\begin{array}{l}\text { Removal } \\
\underset{\text { Efficiency }}{\text { Ef }}\end{array}$ \\
\hline $\mathrm{Fe}$ & - & - & 10 - $1000 \mathrm{mg} / \mathrm{l}$ & $80-90+\%$ & $51 \mathrm{mg} / \mathrm{l}$ & $98 \%$ \\
\hline $\mathrm{Al}$ & - & - & $1-100 \mathrm{mg} / \mathrm{l}$ & $90+\%$ & - & - \\
\hline $\mathrm{Cd}$ & $10 \mu \mathrm{g} / \mathrm{l}$ & $50-60 \%$ & $50-1000 \mu \mathrm{g} / \mathrm{l}$ & $75-90+\%$ & - & - \\
\hline $\mathrm{Cu}$ & $50 \mu \mathrm{g} / \mathrm{l}$ & $50-60 \%$ & $1-100 \mathrm{mg} / \mathrm{l}$ & $80-90+\%$ & $30 \mu \mathrm{g} / \mathrm{l}$ & $89 \%$ \\
\hline $\mathrm{Mn}$ & & & $2-25 \mathrm{mg} / \mathrm{l}$ & & - & - \\
\hline $\mathrm{Ni}$ & - & - & - & - & $65 \mu \mathrm{g} / \mathrm{l}$ & $82 \%$ \\
\hline $\mathrm{Pb}$ & $50 \mu \mathrm{g} / \mathrm{l}$ & $50-60 \%$ & $0.5-10 \mathrm{mg} / \mathrm{l}$ & $80-90+\%$ & $13 \mu \mathrm{g} / \mathrm{l}$ & $100 \%$ \\
\hline $\mathrm{Zn}$ & $300 \mu \mathrm{g} / \mathrm{l}$ & $50-60 \%$ & $10-1000 \mathrm{mg} / \mathrm{l}$ & $75-90+\%$ & - & - \\
\hline BOD & $20-100 \mathrm{mg} / \mathrm{l}$ & $67-80 \%$ & - & - & $70 \mathrm{mg} / \mathrm{l}$ & $95 \%$ \\
\hline $\begin{array}{c}\text { Suspended } \\
\text { Solids } \\
\end{array}$ & $30 \mathrm{mg} / \mathrm{l}$ & $67-80 \%$ & - & - & - & - \\
\hline $\begin{array}{l}\text { Ammonia } \\
\text { Nitrogen }\end{array}$ & $15 \mathrm{mg} / \mathrm{l}$ & $62-84 \%$ & - & - & $230 \mathrm{mg} / \mathrm{l}$ & $91 \%$ \\
\hline $\begin{array}{c}\text { Total } \\
\text { Nitrogen } \\
\end{array}$ & $20 \mathrm{mg} / \mathrm{l}$ & $69-76 \%$ & - & - & - & - \\
\hline $\begin{array}{c}\text { Total } \\
\text { Phosphoru } \\
\text { s } \\
\end{array}$ & $4 \mathrm{mg} / \mathrm{l}$ & $48 \%$ & - & - & $1.9 \mathrm{mg} / \mathrm{l}$ & $99 \%$ \\
\hline Sulfate & - & - & $\begin{array}{c}1,000-10,000 \\
\mathrm{mg} / \mathrm{l}\end{array}$ & $10-30 \%$ & & \\
\hline $\begin{array}{l}\text { Sour } \\
\text { Sour } \\
\text { Mul }\end{array}$ & $\begin{array}{l}\text { Kadlec and Knigh } \\
\text { ITRC } 2003 \\
\text { pottil et al. } 1999\end{array}$ & & & & & \\
\hline
\end{tabular}

\section{Fate and Transport}

Constructed wetlands, like natural wetlands, are subject to fate and transport mechanisms, which could be a concern to regulators, stakeholders, and the public and must be understood and evaluated as part of the design processes. However, these same fate and transport mechanisms are what allow constructed wetlands to treat and remove pollutants from the influent (ITRC 2003). 
Fate and transport mechanism questions identified in ITRC (2003) that must be answered during the design process include:

- Are the contaminants or contaminant byproducts bioavailable to ecological receptors?

- Can contaminants be converted into mobile forms that can impact groundwater?

- Is the contaminant being treated by the constructed wetland toxic to plants?

- Do the plants grown at the site pose additional risks for further ecological exposure or food chain accumulations?

- Is the contaminant transferred into the air or transformed into a more toxic form?

Contaminants entering a wetland can be eliminated, transformed, immobilized, or incorporated, and can pass out of the system. Pollutant concentrations may be reduced by more than one fate mechanism. Transport mechanisms include diffusion, gravity settling, hydraulic travel through the wetland, vegetative translocation, and transfer to groundwater flows in some cases. The chemical properties of the different pollutants influence the fate and transport mechanisms common to those pollutants (ITRC 2003).

Wetlands degrade and eliminate most organic pollutants, other organic matter, and nutrients through biological activity and other processes. Some chemicals will be transformed into less hazardous substances, while others will be moved, immobilized, or concentrated as a result of biological activity within wetland soils, sediment, and detritus layers. These layers bind organic chemicals, inorganic compounds, and metals. Bound biodegradable compounds are either fully degraded or transformed into less toxic compounds. For example, benzene is broken down into carbon dioxide and water through an aerobic microbial process (ITRC 2003).

Metals removal is often a combination of biological and physical processes. Metals and nondegradable compounds are removed from water and accumulate in wetlands, primarily in the soil and sediment layers. Because the metals tightly bind to the soils and sediments by cation exchange and chelation (the process of forming complex compounds that bind metal ions into stable ring structures), these layers can become the environmental endpoint (ITRC 2003, Kadlec and Knight 1996). Plants also intercept and uptake metals, mostly in the roots, but also in the stems, leaves and rhizomes. Upon root death, some portion of the metals may be permanently buried in the sediments (Kadlec and Knight 1996).

The fate of mercury is different from other metals. In reduced wetland sediments, elemental mercury forms and volatilizes, resulting in an atmospheric sink for mercury and subsequent deposition at a distant location (Kadlec and Knight 1996). The most common forms of mercury in aquatic systems are mercuric salts. In wetland systems under anaerobic sediment conditions, the mercuric ions are converted to monoand dimethyl mercury by anaerobic microorganisms, which are more toxic than other forms of mercury. Methylated mercury is a serious problem in aquatic ecosystems because of its toxicity and because it bioaccumulates in the food chain, creating additional environmental problems (Kadlec and Knight 1996).

\section{SUITABILITY OF SUBSURFACE-FLOW WETLANDS FOR THIS APPLICATION}

The constituents that exceed NPDES limits at outfalls H-02 and H-04 (Table 5) are similar in nature and within typical concentrations found in municipal wastewaters, mine drainage and landfill leachate (Table 9), all of which have been successfully treated in constructed wetlands. Required removal rates for Outfalls H-02 and H-04 (Table 5) to bring the effluent to with NPDES limits have been achieved by various types of wetlands (Table 7, Table 8 and Table 9), including SSF wetlands. Therefore it seems likely that a constructed wetland would be capable of treating the flows of the two outfalls adequately. 


\section{TYPICAL DESIGN PARAMETERS \& CONSIDERATIONS}

In general, wetland designs attempt to mimic natural wetlands in overall structure while fostering those wetland processes that are thought to contribute the most to the improvement of water quality. The USDA (1995) recommends keeping the design simple. Complex technological approaches are more prone to failure. Design for minimal maintenance and use of gravity flow, and for the extremes of weather and climate. Design the wetland with the landscape, not against it, integrating the design with the natural topography of the site and mimicking natural systems.

The number of cells needed in a wetland system depends on topography, hydrology, and water quality. USEPA (1993b) recommends that all but the smallest systems divide the surface area required for treatment into two or more parallel cells to provide flexibility for operation and maintenance.

Residence time and the rate and depth of flow through a wetland are critical for adequate treatment and affect the design of a constructed wetland system. Required residence time depends upon contaminant types, degradation/removal rates, and treatment goals (ITRC 2003). Residence times for SF and SSF constructed wetlands are suggested to be from four to 15 days (Tchobanoglous and Burton 1991). Flow velocity should be low (less than $0.5 \mathrm{ft} / \mathrm{second}$ ) and laminar to provide sufficient contact time to attain target removal rates. Flow depths typically range from 0.3 to $2.0 \mathrm{ft}(0.09$ to $0.6 \mathrm{~m})$ for SF systems (Tchobanoglous and Burton 1991), and from 1.6 to $2.6 \mathrm{ft}$ (0.49 to $0.79 \mathrm{~m}$ ) for SSF systems (Cooper et al. 1998).

Constructed wetland design is an iterative process. Site conditions must be evaluated to assess the suitability and potential effectiveness of the proposed constructed wetlands. Site-specific data should be used for the design. Preliminary data required to begin the design process include:

- $\quad$ water budget and influent wastewater characterization

- $\quad$ treatment objectives

- $\quad$ site suitability

$\begin{array}{ll}\text { o } & \text { availability of consistent water source } \\ \circ & \text { available area } \\ \text { o } & \text { site topography } \\ \circ & \text { soils data } \\ \circ & \text { hydrogeology } \\ \circ & \text { climatic patterns } \\ \circ & \text { presence of endangered species (ITRC 2003) }\end{array}$

Figure 8 is a decision tree that summarizes the preliminary stages of evaluating whether a constructed wetland is an appropriate treatment system to meet the treatment goals for any specific site.

\section{Water Budget and Influent Characterization}

The water budget quantifies all water flowing into and out of wetland cells. Inflows include natural flows, process flows, storm water runoff, precipitation, and groundwater. Outflows include evaporation, transpiration, the wetland outlet system, and possibly groundwater. The difference between all inflows and outflows is the required storage capacity. If the wetland is improperly designed, water could leave the wetland at a greater rate than the combined inflows for an extended period of time, causing the wetland to dry out and impacting overall treatment effectiveness. If the inflows are greater than outflows for an extended period of time, the wetland will flood and/or retention times will be too short for sufficient contaminant removal (ITRC 2003). 


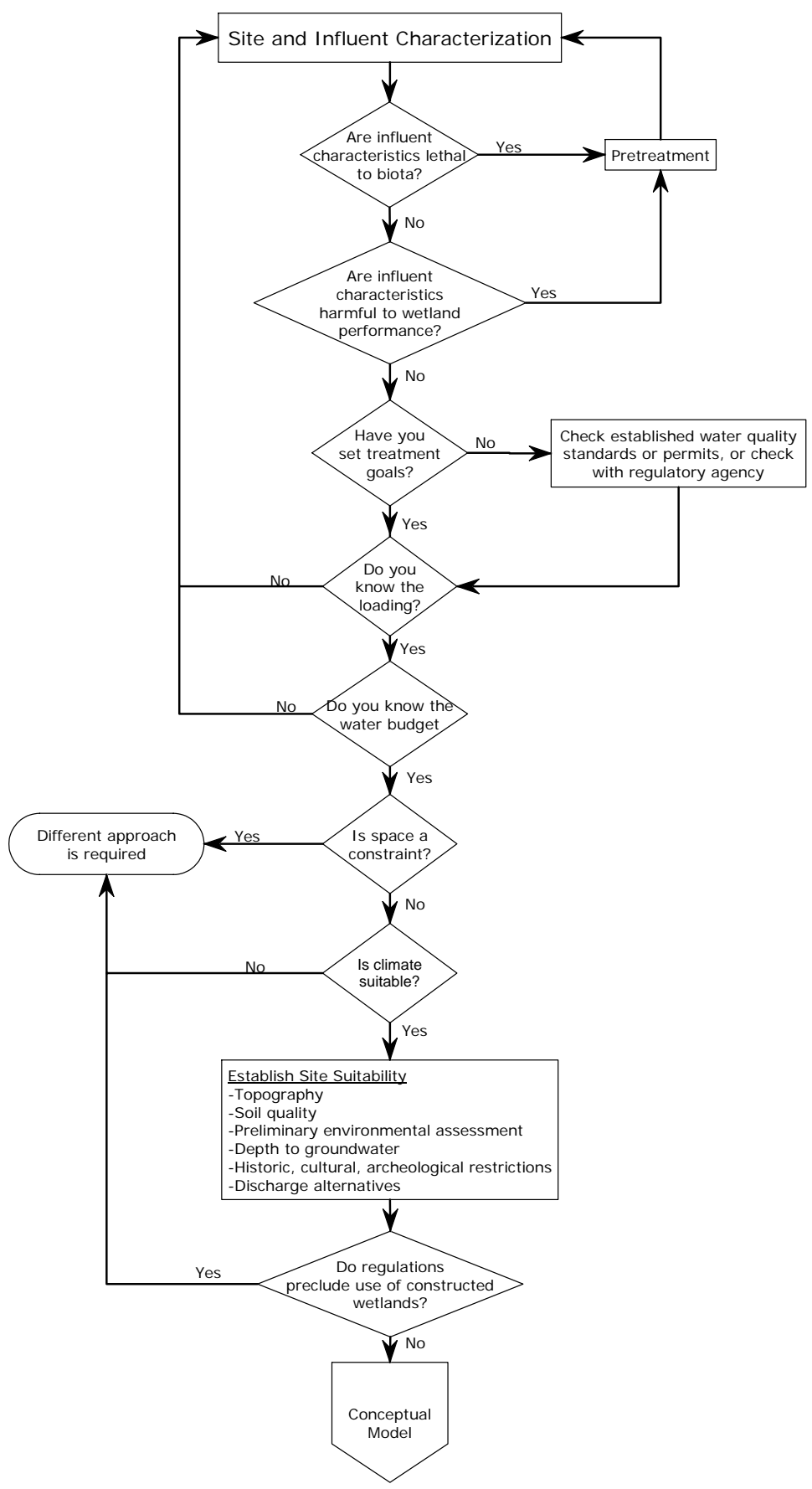

Adapted from ITRC 2003

Figure 8. Constructed Wetland Site Selection Decision Tree

Influent characterization must be determined to understand whether a constructed wetland can effectively treat the influent. Influent characterization includes both water quantity and quality. Knowing the flow rate is critical to sizing the wetland. Low, average, and peak flow must be determined over a representative time interval. Water quality analysis reveals the contaminants and their concentrations, 
which also vary over time. Some constituents may not be removed effectively in wetlands, and thus may not be suitable for wetland treatment. High concentrations of certain contaminants, even temporarily, can disable a treatment wetland or other biological treatment system for extended periods. The treatability of contaminants affects design retention times and, consequently, the size of a wetland. After flows have been estimated and contaminants have been identified and quantified, contaminant-loading estimates can be determined (ITRC 2003).

\section{Treatment Objectives}

Constructed wetlands are limited by the ability of the biota to withstand exposure to the influent contaminant concentrations and other water quality parameters. Contaminant concentrations within the wetland must be below biota survival threshold concentrations. The concentrations in the discharge after treatment must meet regulatory levels. High contaminant concentrations and low permissible effluent concentrations could require long retention times, which require large wetlands, especially if flows are high.

Wetland performance is often judged by removal efficiency, which is the effluent contaminant concentration divided by the influent concentration, but this value can be misleading. Removal efficiency must be coupled with influent concentration to determine whether sufficient treatment can be achieved. Low removal efficiencies do not necessarily result in unacceptable wetland performance. Wetlands can also add contaminants to water flowing through them; background concentrations of nitrogen, phosphorous, BOD, and other water quality parameters are not zero, and may exceed effluent standards in some cases. For example, waterfowl or other wildlife may introduce coliform bacteria exceeding effluent permit requirements. Therefore, removal efficiencies can be negative at times for some contaminants. This must be considered in cases where effluent limits are very stringent (ITRC 2003).

\section{Site Suitability}

Wetlands are best suited to sites having a relatively large amount of available land, a source of year-round water, a long growing season, and a wastewater with low to moderate contaminant concentrations. Depending on flow volumes, contaminant concentrations, and treatment goals, a treatment wetland may require a large tract of land. If the wetland is too small, it may not be able to handle increased flows from storm events in areas of high rainfall. The site should be relatively flat to minimize earth moving costs (ITRC 2003). Cells can be created with dikes on level sites and terraced on sloping sites (USDA 1995).

Site soils information is necessary for predicting the hydrology, determining the design, and determining suitability for wetland plants. Hydric soils can be valuable because they have already conformed to wetland (reduced) conditions. Upland soils can achieve adequate soil-reducing conditions within a few months of project startup. For intermittent flows, low-permeability soils may be desired to maintain saturated conditions. A location with a clay layer may not need a liner to protect groundwater. Highly permeable soils may require a liner so that adequate retention times are achieved and untreated contaminants do not reach groundwater. However, highly permeable soils may be an advantage if groundwater recharge is desired or where in-situ soils will be used for a SSF wetland. Depth to the bedrock at the site is also important because shallow bedrock could potentially cause problems with construction (ITRC 2003).

Wetland plants can be established and thrive most readily in loamy soils, composed of sand, silt, and organic matter. The ideal wetland condition would be a one to three foot layer of loamy soil for plant rooting and optimum microbial growth. The organic matter is important because binding sites on the organic soil particles may allow cation exchange, which removes metals from the water (ITRC 2003). 
Hydrological issues also need to be considered. High groundwater may decrease the infiltration rate or act as a wetland water source, and may make construction difficult. Liners may be necessary to prevent groundwater infiltration, which may pose regulatory problems (ITRC 2003).

Aspects of climate that are important in treatment wetland design include daily and seasonal patterns of precipitation and temperature, both of which affect the biological and physical processes occurring in wetlands. Treatment effectiveness is generally lower in colder weather, so systems built in cold climates may need to be larger or otherwise modified to meet treatment goals. Hot climates may require additional sources of water to keep the wetland from drying out. Typical and extreme patterns of sunlight are also important because sunlight is the main energy source for most physical and biological wetland processes (ITRC 2003).

Biological and ecological factors also need to be considered. As with any other construction project, the presence of endangered or threatened species may restrict construction activities. Wetlands located near human or ecological receptors may pose risk exposure pathways. The presence of wetland indicator plants and animals at the project site provide information on the condition of the soil and depth to groundwater (ITRC 2003).

\section{Decision Trees}

Once it has been determined that a constructed wetland is appropriate for the waste stream and the site, the process would continue with the design and construction of the wetland system. ITRC (2003) developed decision trees for the construction of treatment wetlands for various applications. Figure 9 is a decision tree similar to the one shown in ITRC (2003) for remedial facility wastewater, which typically has contaminants similar to those discharged to Outfalls H-02 and H-04.

\section{RESOURCES REQUIRED}

\section{Estimate of land requirements}

Various methods can be used to determine the surface area required for subsurface flow wetlands: simple design models using rules of thumb, regression equations, first-order models and complex dynamic models. For this document, the simplest methods were used in order to obtain a rough estimate of surface area required for a subsurface wetland for Outfalls H-02 and H-04. Rules of thumb estimates are the fastest but also the roughest design methods. Because they are based on observations from a wide range of systems, climatic conditions and wastewater types, these rules of thumb show a large variation and uncertainty. Actual design of a wetland system would utilize more extensive calculations to determine design.

Residence time is the estimated average time for wastewater to flow completely through the wetland and is a function of the "reactive" volume of the wetland divided by the flow rate. The reactive volume is the volume of water above the substrate for SF wetlands, and the volume of water below the substrate for SSF systems. The required residence time for a treatment wetland is a function of the degradation and removal rates and the treatment goals. The residence time must be greater or equal to the reaction time needed to achieve desired effluent concentrations or treatment will not be adequate. Flow channeling will reduce the actual residence time to less than the calculated value. Treatment wetlands should be designed using a safety factor which increases the size of the wetland (ITRC 2003). As stated previously, suggested residence times for SF and SSF constructed wetlands are from four to 15 days (Tchobanoglous and Burton 1991), depending upon contaminant types, their degradation/removal rates, and treatment goals. 


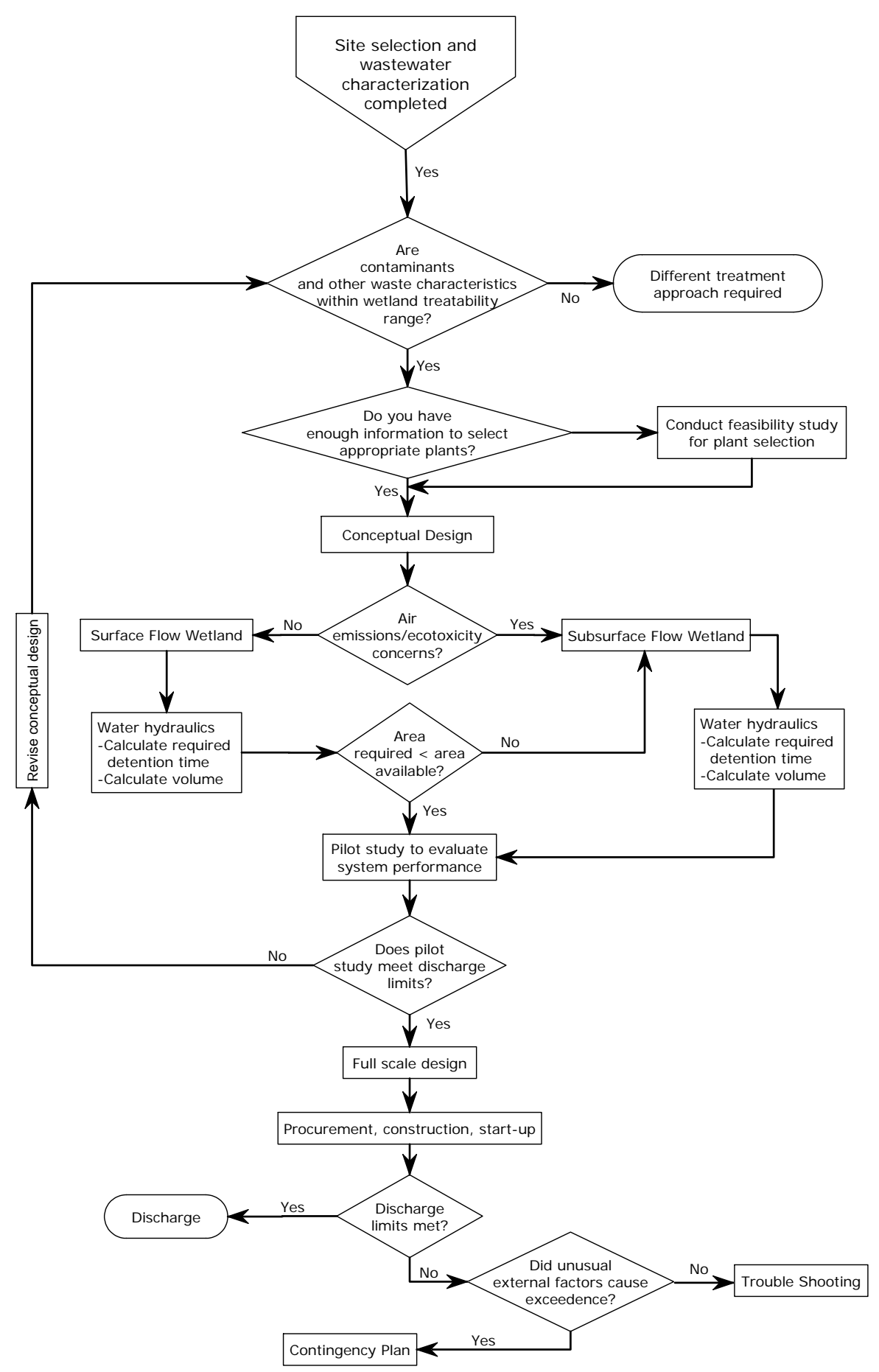

Adapted from ITRC 2003

\section{Figure 9. Decision Tree for Remedial Wastewaters}


Residence time is defined as:

(1) $\quad \mathrm{T}=\mathrm{V} / \mathrm{Q}$

where $\mathrm{T}=$ residence time (days)

$\mathrm{V}=$ wetland volume $\left(\mathrm{m}^{3}\right)$

$\mathrm{Q}=$ average flow rate $\left(\mathrm{m}^{3} /\right.$ day)

A preliminary estimate of the land required for the wetland cells can be obtained using a variation of the above equation.

$$
\mathrm{A}=\mathrm{TQ} \times 2.471 \mathrm{E}-02 / \mathrm{d}
$$

where $\mathrm{A}=$ surface area for the constructed wetland (acres)

$\mathrm{d}=$ depth of the wetland cell $(\mathrm{cm})$

Using typical wetland depths for subsurface flow wetlands ( $49-79 \mathrm{~cm}$, or 1.6 to $2.6 \mathrm{ft}$ ) and surface flow wetlands ( 9 - $60 \mathrm{~cm}$, or 0.3 to $2.0 \mathrm{ft}$ ), listed in ITRC (2003) and the residence times recommended by Tchobanoglous and Burton (1991) (4 to 15 days), ranges of estimated area required per unit of flow were calculated using equation (2). These are shown in Table 10 along with rule-of-thumb design criteria obtained from other sources.

A preliminary estimate of the amount of land required for a SSF or SF wetland also can be obtained using recommended hydraulic loading rates. The hydraulic loading rate $(\mathrm{q})$, which is the flow rate per unit area, generally varies from $0.7-5 \mathrm{~cm} / \mathrm{d}(0.3$ and 2 in/day) for constructed SF wetlands and $2-20 \mathrm{~cm} / \mathrm{d}(0.8-8$ in/day) for constructed SSF wetlands (WPCF 1990). USEPA's North American Database, a compilation of data from actual treatment wetlands in the United States and Canada, lists median hydraulic loading rate values of $1.4 \mathrm{~cm} / \mathrm{d}(0.5 \mathrm{in} / \mathrm{d})$ and $17.4 \mathrm{~cm} / \mathrm{d}(6.9 \mathrm{in} / \mathrm{d})$ for SF and SSF wetlands, respectively (ITRC 2003). The estimated surface area required can be calculated from the hydraulic loading rate using equation (3) below:

$$
\mathrm{A}=\mathrm{Q} \times 2.471 \mathrm{E}-02 / \mathrm{q}
$$

where $\mathrm{A}=$ surface area for the constructed wetland (acres)

$\mathrm{Q}=$ average flow rate $\left(\mathrm{m}^{3} /\right.$ day)

$\mathrm{q}=$ hydraulic loading rate $(\mathrm{cm} /$ day)

Using the typical hydraulic loading rates for SF and SSF wetlands, listed above, ranges of estimated area required per unit of flow can be calculated using equation (3). These are shown in Table 10 along with rule-of-thumb design criteria obtained from other sources.

Another parameter used in sizing wetlands is the areal loading rate (ALR). The ALR is the maximum removal rate of a pollutant mass per unit surface area of a wetland per daily input (ITRC 2003).

$$
\mathrm{ALR}=\mathrm{Q} \times \mathrm{C} / \mathrm{A}
$$

where $\mathrm{ALR}=$ areal loading rate $\left(\mathrm{g} / \mathrm{m}^{2} /\right.$ day $)$

$\mathrm{Q}=$ influent flow rate $\left(\mathrm{m}^{3} / \mathrm{d}\right)$

$\mathrm{C}=$ pollutant concentration $\left(\mathrm{mg} / \mathrm{L}=\mathrm{g} / \mathrm{m}^{3}\right)$

$\mathrm{A}=$ surface area $\left(\mathrm{m}^{2}\right)$ of the SSF wetland. 
Table 10. Rule of Thumb Design Criteria for SSF and SF Constructed Treatment Wetlands

\begin{tabular}{|c|c|c|c|c|}
\hline \multirow{2}{*}{$\begin{array}{l}\text { Criterion } \\
\text { Method or Source }\end{array}$} & \multicolumn{4}{|c|}{ Value range } \\
\hline & $\begin{array}{c}\text { ITRC (2003) and } \\
\text { Tchobanoglous and Burton } \\
\text { (1991) }\end{array}$ & $\begin{array}{l}\text { WPCF } \\
(1990)\end{array}$ & $\begin{array}{l}\text { Wood } \\
(1995)\end{array}$ & $\begin{array}{l}\text { Kadlec and } \\
\text { Knight (1996) }\end{array}$ \\
\hline \multicolumn{5}{|l|}{ SSF WETLAND } \\
\hline $\begin{array}{l}\text { Hydraulic retention time } \\
\text { (days) }\end{array}$ & $4-15$ & NA & $2-7$ & $2-4$ \\
\hline $\begin{array}{l}\text { Hydraulic loading rate (cm } \\
\text { day }^{-1} \text { ) }\end{array}$ & NA & $2-20$ & $0.2-3.0$ & $8-30$ \\
\hline Cell depth (cm) & $49-79$ & NA & n.g. & $30-60$ \\
\hline $\begin{array}{l}\text { Calculated areal } \\
\text { requirement (acre } / \mathrm{m}^{3} / \text { day) }\end{array}$ & $0.001-0.008$ & $\begin{array}{c}0.001- \\
0.01\end{array}$ & $\begin{array}{c}0.002- \\
0.017\end{array}$ & $0.0008-0.003$ \\
\hline \multicolumn{5}{|l|}{ SF WETLAND } \\
\hline $\begin{array}{l}\text { Hydraulic retention time } \\
\text { (days) }\end{array}$ & $4-15$ & NA & n.g. & $7-10$ \\
\hline $\begin{array}{l}\text { Hydraulic loading rate (cm } \\
\text { day }^{-1} \text { ) }\end{array}$ & NA & $0.7-5$ & n.g. & $1.5-6.5$ \\
\hline Cell depth (cm) & $9-60$ & NA & n.g. & $15-45$ \\
\hline $\begin{array}{l}\text { Calculated areal } \\
\text { requirement (acre/m³/day) }\end{array}$ & $0.002-0.04$ & $\begin{array}{c}0.005- \\
0.03\end{array}$ & n.g. & $0.004-0.02$ \\
\hline
\end{tabular}

NA not applicable

n.g. not given by the source

Areal loading rates can be used to give sizing estimates for both planning and final design of wetlands systems from projected pollutant mass loads and effluent requirements.

Area requirements can also be calculated by reaction rate. Reaction rates are functions of the reactant concentrations and specific rate constants, which are a function of temperature. Removal rates are higher initially, when the concentration is at its highest, but the removal rates decrease as the water travels through the wetlands and the concentration decreases. A first order model used by Kadlec and Knight (1996) incorporated background concentrations and can be used for preliminary calculations of required wetland surface area (ITRC 2003):

(5) $\mathrm{A}=-\mathrm{Q} / \mathrm{k}_{\mathrm{A}}\left[\ln \left(\left([\right.\right.\right.$ Pollutant $]$ outlet $\left.-\mathrm{P}^{*}\right) /([$ Pollutant $]$ inlet-P* $\left.\left.)\right)\right]$

Where $\mathrm{Q}=$ average flow rate (cm3/day)

$\mathrm{k}_{\mathrm{A}}=$ areal rate constant $\left(\right.$ day $\left.^{-1}\right)$

[Pollutant $]=$ concentration of pollutant $(\mathrm{g} / \mathrm{L})$

$\mathrm{P}^{*}=$ background pollutant concentration 
For the purposes of this document, estimates of the wetland surface area required to treat effluents from Outfalls H-02 and H-04 are based on those parameters given in Table 10 rather than these last two calculation methods, which are pollutant-specific. Combined average flows for the two outfalls are approximately $0.13 \mathrm{mgd}$ (Table 1 ) or $490 \mathrm{~m}^{3} /$ day, and maximum flows are $2.33 \mathrm{mgd}$ or $8,800 \mathrm{~m}^{3} /$ day. Minimum wetland surface area required based on the average flow and using various calculation methods listed in Table 10 are shown below in Table 11. These areas do not take into account additional storm water influent or the safety factor discussed above. In comparison, USEPA (1993b) lists the sizes of operating subsurface flow wetlands receiving similar flow rates of municipal wastewater to be between 0.7 and 3.7 acres (0.3 - $1.5 \mathrm{ha})$.

Table 11. Estimated Minimum Wetland Surface Area for Combined Outfalls H-02 and H-04 (Using Average Flows)

\begin{tabular}{|l|c|c|c|c|}
\hline Criterion & Value range & & \\
\hline Method or Source & $\begin{array}{c}\text { ITRC (2003) and } \\
\text { Tchobanoglous and } \\
\text { Burton (1991) }\end{array}$ & WPCF (1990) & Wood (1995) & $\begin{array}{c}\text { Kadlec and } \\
\text { Knight (1996) }\end{array}$ \\
\hline $\begin{array}{l}\text { SSF Surface Area } \\
\text { Range (acres) }\end{array}$ & $0.5-4$ & $0.5-5$ & $1-8$ & $0.4-1.5$ \\
\hline $\begin{array}{l}\text { SF Surface Area } \\
\text { Range (acres) }\end{array}$ & $1-20$ & $2-15$ & NA & $2-10$ \\
\hline
\end{tabular}

\section{Estimate of costs}

A variety of factors affect the cost of constructed wetlands, including:

- detention time (longer detention time translates to a larger wetland),

- treatment goals (higher removal rates require longer detention times, thus larger wetlands),

- media type, source and availability,

- type of liner (if required)

- bed depth (deeper systems require less liner),

- pretreatment type,

- number of cells (more cells require more hydraulic control structures and liners), and

- terrain (which affects the amount of grading required) (ITRC 2003).

General cost estimates for constructed wetlands can be obtained from various sources. USEPA (1993b) reported that the capital costs averaged around $\$ 87,000 /$ acre $(\$ 215,000 /$ ha) for SSF wetland systems and about $\$ 22,000 /$ acre $(\$ 54,000 / h a)$ for SF systems. The major cost difference between the two types of systems was in procuring, transporting and installing the rock or gravel media, which is the most important factor influencing capital cost for a SSF wetland. Gravel accounts for approximately $40-50 \%$ of the total cost for a $50,000-\mathrm{ft}^{2}$ ( 0.5 ha or 1.1 acres) system, with the percentage increasing as the system gets larger. Gravel usually costs about $\$ 9.50 /$ ton or $\$ 13 / \mathrm{yd}^{3}\left(\$ 17 / \mathrm{m}^{3}\right)$ throughout the United States. Delivered costs can exceed $\$ 20 / \mathrm{yd}^{3}\left(\$ 26 / \mathrm{m}^{3}\right)$. Some states, Florida for example, are considering the use of recycled concrete rubble as SSF wetland media (ITRC 2003).

The type of liner used, if any, can also significantly affect the cost. Liner costs depend on the quantity, thickness, and type of material specified. In general, liners account for approximately $15-25 \%$ of the total 
cost, with the percentage declining as the system gets larger (ITRC 2003). The percentage increases when expensive liner materials are used and as the number of cells increases. In some cases, a liner can be eliminated if soils have high clay content. The addition of bentonite to the soil or the use of in-situ clay soils in lieu of a liner may seem desirable, but the additional costs of testing and compaction can add significant costs to the project and may even exceed the cost of a 30-mil PVC liner. However, because most liners are petroleum-based products, prices could easily rise with oil prices, making clay soils and bentonite more competitive. ITRC (2003) listed an installed cost for a 30-mil PVC liner of $38-40 \$ / \mathrm{ft}^{2}$ $\left(\$ 4.10-\$ 4.30 / \mathrm{m}^{2}\right)$ for small systems and $30-35 \pitchfork / \mathrm{ft}^{2}\left(\$ 3.20-\$ 3.80 / \mathrm{m}^{2}\right)$ in systems $100,000 \mathrm{ft}^{2}\left(9,000 \mathrm{~m}^{2}\right.$ or 2.3 acres) and larger. Other types of liners ranged from $35-90 \$ / \mathrm{ft}^{2}\left(\$ 3.80-\$ 9.70 / \mathrm{m}^{2}\right)$ in systems $100,000 \mathrm{ft}^{2}\left(9,000 \mathrm{~m}^{2}\right.$ or 2.3 acres $)$ and larger.

General construction costs have changed considerably over recent years. The Engineering News Record (ENR) Construction Cost Index can be used to adjust construction costs from previous years to current conditions. The Construction Cost Index is a representative construction cost composed of a fixed number of common labor hours and a specific set of materials costs, collected from across the country every month. The Construction Cost Index uses 200 hours of common labor, multiplied by the 20-city average rate for wages and fringe benefits, plus the 20-city average price for 25 cwt of fabricated standard structural steel, and local prices for 1.128 tons of bulk portland cement and 1,088 board-ft of 2x4 lumber. The Construction Cost Index measures how much it costs to purchase this hypothetical package of goods and labor compared to what it cost in the base year. Although this mix of labor and materials is not truly accurate for a constructed wetland because of the difference in construction materials needed for a wetland vs. those used in generating the index, the Construction Cost Index does provide a means to roughly update wetland construction costs reported in earlier years.

Using the average Construction Cost Index for 1993 (5210) and the Construction Cost Index reported for August 2004 (7188) (ENR 2004a), the costs reported in USEPA (1993b) can be roughly translated to 2004 costs by multiplying the 1993 cost by the ratio of the updated index to the 1993 index (in this case: 2004 cost $=1993$ cost $\times 7188 / 5210$ ). This approximation of 2004 costs is shown in Table 12 .

USEPA (2000b,c) reported total calculated capital costs for a 3.2 acre (1.3 ha) wetland with a plastic membrane liner treating $0.1 \mathrm{mgd}\left(380 \mathrm{~m}^{3} / \mathrm{d}\right)$ to be $\$ 466,700$ for a SSF wetland (USEPA 2000b) and $\$ 259,000$ for a SF wetland (USEPA 2000c). Costs for constructing the same SSF and SF wetlands using a native soil liner were $\$ 362,500$ and $\$ 154,800$, respectively. In contrast, a conventional treatment system designed for the same size waste stream was reported to cost $\$ 1,104,500$ (USEPA 2000b,c). Using the ENR Construction Cost Index listed in the USEPA document (6039, for June 1999) and the Construction Cost Index reported for August 2004 (7188) (ENR 2004a), the USEPA (2000b,c) costs can be updated to 2004 costs as discussed above. These are shown in Table 12.

A cost estimate reported in ITRC (2003) for a 50,000 $\mathrm{ft}^{2}$ wetland $\left(4,600 \mathrm{~m}^{2}\right.$ or 1.1 acres) is itemized in Table 13 below. This cost estimate of $\$ 121,980$ is roughly equivalent to an August 2004 cost of $\$ 131,000$ (using the average Construction Cost index for 2003: 6694). This translates to $\$ 119,000 /$ acre (\$294,000/ha), which is close to the updated estimate from USEPA (1993b) (Table 12) of \$120,000/acre (\$297,000/ha). 
Table 12. Updated Estimate of Capital Costs

\begin{tabular}{|c|c|c|}
\hline Item & Reported Cost & Updated 2004 Cost \\
\hline $\begin{array}{l}\text { Capital costs per acre for SSF } \\
\text { wetland systems }\end{array}$ & $\$ 87,000 /$ acre $^{\text {a }}$ & $\$ 120,000$ acre $^{\text {b }}$ \\
\hline $\begin{array}{l}\text { Capital costs per acre for SF } \\
\text { wetland systems }\end{array}$ & $\$ 22,000 /$ acre $^{\text {a }}$ & $\$ 30,000 /$ acre $^{b}$ \\
\hline $\begin{array}{l}\text { Capital costs for a } 0.1 \text { mgd SSF } \\
\text { wetland system with a liner }\end{array}$ & $\begin{array}{l}\$ 466,700^{c} \\
\text { or } \$ 146,000 / \text { acre }\end{array}$ & $\begin{array}{l}\$ 555,000^{\mathrm{e}} \\
\text { or } \$ 173,000 / \text { acre }\end{array}$ \\
\hline $\begin{array}{l}\text { Capital costs for a } 0.1 \text { mgd SF } \\
\text { wetland systems with a liner }\end{array}$ & $\begin{array}{l}\$ 259,000^{\mathrm{d}} \\
\text { or } \$ 81,000 \text { /acre }\end{array}$ & $\begin{array}{l}\$ 308,000^{\mathrm{e}} \\
\text { or } \$ 96,000 / \text { acre }\end{array}$ \\
\hline $\begin{array}{l}\text { Capital costs for a } 0.1 \text { mgd SSF } \\
\text { wetland system without a liner }\end{array}$ & $\begin{array}{l}\$ 362,500^{c} \\
\text { or } \$ 113,000 / \text { acre }\end{array}$ & $\begin{array}{l}\$ 431,000^{\mathrm{e}} \\
\text { or } \$ 135,000 / \text { acre }\end{array}$ \\
\hline $\begin{array}{l}\text { Capital costs for a } 0.1 \mathrm{mgd} \text { SF } \\
\text { wetland systems without a liner }\end{array}$ & $\begin{array}{l}\$ 154,800^{\mathrm{d}} \\
\text { or } \$ 48,000 / \text { acre }\end{array}$ & $\begin{array}{l}\$ 184,000^{\mathrm{e}} \\
\text { or } \$ 58,000 / \text { acre }\end{array}$ \\
\hline $\begin{array}{l}\text { Capital costs for a } 0.1 \mathrm{mgd} \\
\text { conventional wastewater } \\
\text { treatment system }\end{array}$ & $\$ 1,104,500^{c}$ & $\$ 1,315,000^{e}$ \\
\hline \\
\hline \multicolumn{3}{|c|}{ Based on Construction Costs Indices found in ENR (2004a) for 1993 and for August 2004} \\
\hline \multicolumn{3}{|l|}{$\begin{array}{l}\text { Source: USEPA 2000b } \\
\text { Source: USEPA 2000c }\end{array}$} \\
\hline \multicolumn{3}{|l|}{$\begin{array}{l}\text { Source: USEPA 2000c } \\
\text { Based on Construction C }\end{array}$} \\
\hline
\end{tabular}

Table 13. Cost of a Typical $50,000 \mathrm{ft}^{2}\left(4,600 \mathrm{~m}^{2}\right.$ or 1.1 acres) SSF Wetland

\begin{tabular}{|l|l|c|}
\hline \multicolumn{1}{|c|}{ Component } & \multicolumn{1}{c|}{ Price/Unit } & Total (\$) \\
\hline Excavation/Compaction & $\$ 1.75 / \mathrm{yd}^{3}\left(\$ 2.29 / \mathrm{m}^{3}\right)$ & 13,000 \\
\hline Gravel & $\$ 16 / \mathrm{yd}^{3}\left(\$ 21 / \mathrm{m}^{3}\right)$ & 51,900 \\
\hline Liner, 30-mil PVC & $35 \$ / \mathrm{ft}^{2}\left(\$ 3.80 / \mathrm{m}^{2}\right)$ & 19,250 \\
\hline Plants, 18 inch centers & 60థ/each & 13,330 \\
\hline Plumbing & & 7,500 \\
\hline Control Structures & & 7,000 \\
\hline Other & & 10,000 \\
\hline Total & & 121,980 \\
\hline
\end{tabular}

Source: ITRC 2003

Operation and maintenance costs include influent and effluent testing, water level adjustment, maintenance of inflow, outflow and distribution devices, weed control, odor control, control of nuisance pests and insects, and maintenance of berms and dikes. The largest single cost is generally the cost of testing influent and effluent, which depends on frequency of sampling, the number of water quality parameters, and the number of samples. Water levels should be checked periodically to ensure that water is flowing, that no surfacing has occurred in an SSF system, and that breaches have not occurred. Inlet and outlet piping must be inspected and maintained, removing clogs, debris and trapped sediment and periodically flushing pipes and manifolds. Flow splitters should be checked and cleaned periodically. 
These activities will ensure proper water flow and water level. Weeds should be controlled around the edges, and large weeds should be removed. Odors can be reduced by lowering water levels below the substrate or reducing solid loading. A significant potential maintenance activity for SF systems is the control of nuisance pests, including beavers, mosquitoes, and other insects (ITRC 2003).

Reported costs for operations and maintenance (O\&M) indicate that wetlands are very low-cost systems to operate. ITRC (2003) reported an annual operations and maintenance cost of $\$ 29,550$ for a 3 mgd $\left(11,000 \mathrm{~m}^{3} /\right.$ day) SSF system, including the cost of operating the pre-treatment units. A smaller SSF system ( $0.4 \mathrm{mgd}$, or $\left.1,500 \mathrm{~m}^{3} / \mathrm{day}\right)$ had an annual operating budget of $\$ 10,000$. This translates to operating cost of $2.7-6.8 \$ / 1000$ gallons treated $\left(0.7-1.8 \$ / \mathrm{m}^{3}\right)$. Crites and Ogden (1998) reported O\&M costs of $4-8 \$ / 1000$ gallons $\left(1.1-1.2 థ / \mathrm{m}^{3}\right)$ treated for SSF systems, compared to $10-30 \$ / 1000$ gallons $\left(2.6-7.9 \$ / \mathrm{m}^{3}\right)$ treated for SF systems (USEPA 2000a). The difference in cost between the two types of systems may be because SF systems are typically larger for a given flow rate than SSF systems. USEPA (2000b,c) reported a calculated O\&M cost of \$6,000/yr for 3.2 acre (1.3 ha) SSF and SF systems treating $0.1 \mathrm{mgd}\left(380 \mathrm{~m}^{3} /\right.$ day), or $16 \$ / 1000$ gallons. In contrast, O\&M cost for a $0.1 \mathrm{mgd}\left(380 \mathrm{~m}^{3} / \mathrm{day}\right)$ conventional treatment facility was listed as $\$ 106,600 / \mathrm{yr}$ (\$2.90/1000 gallons) (USEPA 2000b,c). These costs can also be updated in a manner similar to the capital costs using ENR's Common Labor Index, which is the labor component of ENR's Construction Cost Index and tracks the union wage, plus fringe benefits, for laborers. These updated costs are shown in Table 14.

Table 14. Updated Estimate of O\&M Costs

\begin{tabular}{|c|c|c|}
\hline Type and Source of Data & Reported Cost & Updated 2004 Cost \\
\hline $\begin{array}{l}\text { SSF wetland system, ITRC } \\
\text { (2003) }\end{array}$ & $2.7-6.8 \$ / 1000$ gallons & $2.8-7.1 \$ / 1000$ gallons $^{a}$ \\
\hline $\begin{array}{l}\text { SSF wetland system, Crites and } \\
\text { Ogden (1998) }\end{array}$ & $4-8 థ / 1000$ gallons & $5-10 \$ / 1000$ gallons $^{b}$ \\
\hline $\begin{array}{l}\text { SF wetland system, Crites and } \\
\text { Ogden (1998) }\end{array}$ & $10-30 \$ / 1000$ gallons & $13-38 \$ / 1000$ gallons $^{b}$ \\
\hline $\begin{array}{l}\text { SSF or SF wetland system, } \\
\text { USEPA }(2000 b, c)\end{array}$ & 16\$/1000 gallons & $19 \$ / 1000$ gallons $^{c}$ \\
\hline $\begin{array}{l}\text { Conventional wastewater } \\
\text { treatment system USEPA } \\
(2000 \mathrm{~b}, \mathrm{c})\end{array}$ & $\$ 2.90 / 1000$ gallons & $\$ 3.50 / 1000$ gallons $^{c}$ \\
\hline $\begin{array}{ll}\text { a } & \text { Based on Common Labor Indi } \\
\text { c } & \text { Based on Common Labor Indi } \\
\text { c } & \text { Based on Common Labor Indi }\end{array}$ & $\begin{array}{l}\text { for average } 2003(14386) \text { an } \\
\text { for average } 1998(12024) \text { an } \\
\text { for June } 1999(12373) \text { and } \mathrm{fc}\end{array}$ & $\begin{array}{l}04 \text { (15038) (ENR 2004b) } \\
04 \text { (15038) (ENR 2004b) } \\
\text { (15038) (ENR 2004b) }\end{array}$ \\
\hline
\end{tabular}

These cost data can be used to develop a rough idea of the costs for constructing and operating a SSF wetland for outfalls H-02 and H-04. Based on a cost estimate of \$120,000/acre (updated from USEPA 1993b, Table 12) and the sizing estimates shown in Table 11, costs for a SSF wetland using average flows for outfalls H-02 and H-04 could be very roughly predicted to be between $\$ 48,000$ ( 0.4 acres or 0.16 ha) and $\$ 600,000$ (5 acres or 2 ha), with an outside estimate of $\$ 960,000$ (8 acres or 3 ha). Using a cost estimate of $\$ 173,000 /$ acre (updated from USEPA 2000b, Table 12), the cost estimate ranges from $\$ 69,000$ ( 0.4 acres or $0.16 \mathrm{ha}$ ) to $\$ 865,000$ (5 acres or $2 \mathrm{ha}$ ). These costs are shown in Table 15 . Using the range of dollars per unit flow O\&M costs reported above (2.7-19 $\$ / 1000$ gallons, or $\left.0.7-5 \$ / \mathrm{m}^{3}\right)$, annual O\&M costs for a SSF wetland for outfalls $\mathrm{H}-02$ and $\mathrm{H}-04$ could be expected to be between approximately $\$ 1,300$ and $\$ 9,000$ using average outfall flows (Table 15). These estimates do not take into account any 
additional acreage necessary to size the wetland to handle storm flows. Increasing the size of the wetland to handle such flows would necessarily increase both the construction and operations/maintenance costs. These estimates are intended for determining the initial feasibility of building a constructed wetland for these outfalls. More detailed estimates would be needed before proceeding with a constructed wetland project.

Rough cost estimates for a SF wetland for outfalls H-02 and H-04 can be calculated with these data also. Based on cost estimates of $\$ 30,000 /$ acre $(\$ 74,000 /$ ha) (updated from USEPA 1993b) to $\$ 96,000 /$ acre (\$240,000/ha) (updated from USEPA 2000c, Table 12) and the sizing estimates shown in Table 11 (1 to 20 acres or 0.4 to 8 ha), costs for a SF wetland using average flows for outfalls $\mathrm{H}-02$ and $\mathrm{H}-04$ could be very roughly predicted to be between $\$ 30,000$ and $\$ 1,900,000$ (Table 15). Using the range of dollars per unit flow O\&M costs reported above (13 to $38 \$ / 1000$ gallons, or 3 to $10 \AA / \mathrm{m}^{3}$ ), annual O\&M costs for a SF wetland for outfalls H-02 and H-04 could be expected to be between approximately \$6,200 and $\$ 18,000$ using average outfall flows (Table 15). Again, these estimates do not take into account any additional acreage necessary for handling storm flows, and more detailed estimates would be needed before proceeding with a constructed wetland project.

Table 15. Preliminary Cost Comparison of a SSF vs. a SF Wetland for Outfalls H-02 and H-04

\begin{tabular}{|l|l|}
\hline Unit Cost & Range of Total Cost \\
\hline SSF Unit Cost & \\
\hline Capital Costs of $\$ 120,000 /$ acre & $\$ 48,000-\$ 600,000^{\mathrm{a}}$ \\
\hline Capital Cost of $\$ 173,000 /$ acre & $\$ 69,000-\$ 865,000^{\mathrm{a}}$ \\
\hline Annual O\&M Costs & $\$ 1,300-\$ 9,000^{\mathrm{b}}$ \\
\hline SF Unit Cost & \\
\hline Capital Costs of $\$ 30,000 /$ acre & $\$ 30,000-\$ 720,000^{\mathrm{c}}$ \\
\hline Capital Cost of $\$ 96,000 /$ acre & $\$ 96,000-\$ 1,900,000^{\mathrm{c}}$ \\
\hline Annual O\&M Costs & $\$ 6,200-\$ 18,000^{\mathrm{d}}$ \\
\hline
\end{tabular}

a Based on size estimate of 0.4 to 5 acres

b Based on range of 2.8 to $19 \$ / 1000$ gallons

c Based on size estimate of 1 to 20 acres

d Based on range of 13 to $38 \$ / 1000$ gallons

\section{CONCLUSION}

Constructed wetlands can be used to effectively treat a variety of types of wastewater, including those contaminated with metals, such as the effluent from outfalls H-02 and H-04. Such wetlands are designed to take advantage of the chemical and biological processes of natural wetlands to remove contaminants from the wastewater. Constructed wetlands also have significantly lower capital costs and total lifetime costs than conventional treatment systems.

The contaminants that exceed NPDES limits at outfalls H-02 and H-04 are similar in nature and within typical concentrations found in wastewaters that have been successfully treated in constructed wetlands. Required removal rates (>90\%) to bring H-02 and H-04 effluent to within NPDES limits have been achieved by various types of wetlands, including both SF and SSF wetlands. Therefore it seems likely 
that a constructed wetland would be capable of treating the flows of outfalls $\mathrm{H}-02$ and $\mathrm{H}-04$ sufficiently and cost effectively.

Land requirements and scoping-level costs for SSF and SF wetlands could be roughly predicted using size and cost per acre estimates from various sources. The wide range of costs reflects the variation in unit cost estimates reported in the literature and the flexibility in wetland design. Scoping-level costs for a SSF wetland for outfalls H-02 and H-04 were calculated to be between \$48,000 (0.4 acres at $\$ 120,000 /$ acre) and $\$ 865,000$ (5 acres at $\$ 173,000 /$ acre) when using average outfall flows to estimate the size requirements. Scoping-level costs for a SF wetland treating the same wastewater were calculated to be between \$30,000 (1 acre at \$30,000/acre) and \$1,900,000 (20 acres at \$96,000/acre). Annual O\&M costs for a SSF wetland for outfalls $\mathrm{H}-02$ and $\mathrm{H}-04$ could be expected to be between approximately $\$ 1,300$ and \$9,000 using average outfall flows. Comparable O\&M costs for a SF wetland could be expected to be between approximately $\$ 6,200$ and $\$ 18,000$.

These estimates do not take into account additional acreage necessary to size the wetland to handle storm flows. Increasing the size of the wetland to handle such flows would necessarily increase both the construction and operations/maintenance costs. These estimates are intended for determining the initial feasibility of building a constructed wetland. More detailed estimates would be needed before proceeding with a constructed wetland project.

\section{REFERENCES}

Berner, R.A. 1980. Early Diagenesis: A Theoretical Approach, p. 241. Princeton, N.J. Princeton University Press.

Best, G.G. 1987. Natural Wetlands - Southern Environment: Wastewater to Wetlands, Where Do We Go from Here? pp. 99-120. in K.R. Reddy and W.H. Smith (Eds.), Aquatic Plants for Water Treatment and Resource Recovery. Magnolia Publishing, Orlando, Florida.

Boyle, R.W. 1965. Geology, Geochemistry, and Origin of the Lead-Zinc-Silver Deposits of the Keno Hill-Galena Hill Area, Yukon Territory. Geological Survey of Canada, Bulletin 111.

Boyle, R.W. 1977. Cupriferous Bogs in the Sackville Area, New Brunswick, Canada. J. Geoch. Expl., 8: 495-528.

CH2M Hill. 1991 Grand Strand Water and Sewer Authority Central Wastewater Treatment Plant Wetlands Discharge. Central Slough Pilot Study Fifth Annual Report, July 1990 - June 1991. Prepared for Grand Strand Water and Sewer Authority.

CH2M Hill. 1992. Carolina Bay Natural Land Treatment Program. Final Report. Prepared for Grand Strand Water and Sewer Authority.

Cooper, P., B. Green, and A. Thornton, 1998, "Reed Beds and Constructed Wetlands for Wastewater Treatment," in course Creating and Using Wetlands for Wastewater and Stormwater Treatment and Water Quality Improvement. University of Wisconsin-Madison.

Crites, R.W. and M.H. Ogden. 1998. Costs of Constructed Wetlands Systems. Presented to WEFTEC, WEF $71^{\text {st }}$ Annual Conference, Orlando, FL. 
DeLaune, R.D., C.M. Reddy and W.H. Patrick, Jr. 1981. Accumulation of Plant Nutrients and Heavy Metals through Sedimentation Processes and Accretion in a Louisiana Salt Marsh. Estuaries 4:328-334.

Drever, J.I. 1988. The Geochemistry of Natural Waters. 2nd ed. Englewood Cliffs, N.J.: Prentice-Hall, p. 347.

Dusel, C.E., Jr., and C.W. Pawlewski. 2000. Constructed Wetlands Offer Flexibility. http://www.landandwater.com/features/vol41no6/vol41no6_2.html. September 24, 2004 . URS Greiner, Inc., Buffalo, NY

Eapaea, M.P., D.L. Parry, and B.N. Noller. 1995, Retention of Arsenic and Metals in a Tropical Wetland following Dewatering from Tom’s Gully Gold Mine. Proceedings from 4th Environment Chemistry Conference, Chemistry in Tropical and Temperate Environments. Darwin, Northern Territory, Australia, July 9-14. Royal Australian Chemical Institute, Environment Division.

Edwards, M.E. 1993. Unpublished data from Tennessee Valley Authority. As reported in ITRC (2003).

Eger, P., K.A. Lapakko, and P. Otterson. 1980. Trace Metal Uptake by Peat: Interaction of a White Cedar Bog and Mining Stockpile Leachate, Proceedings from 6th International Peat Congress, pp. 542-47. Duluth, Minn., August 17-23.

Eger, P. and K.A. Lapakko, 1988. Nickel and Copper Removal from Mine Drainage by a Natural Wetland, Proceedings from 1988 Mine Drainage and Surface Mine Reclamation Conference, Mine Water and Mine Waste (Volume 1), pp. 301-309. Pittsburgh, Pa., April 19-21. USDI, Bureau of Mines IC9183.

Engineering News Record (ENR). 2004a. Construction Cost Index History. http://enr.construction.com/features/coneco/subs/constIndexHist.asp. August 30, 2004. The McGrawHill Companies, Inc.

Engineering News Record (ENR). 2004b. ENR’s Common Labor Index (1989-2004). http://enr.construction.com/features/coneco/subs/04-commonLaborIndex.asp. October 8, 2004. The McGraw-Hill Companies, Inc.

Faulkner, B.B. and F.K. Miller. 2003. Improvement of Water Quality by Land Reclamation and Passive Systems at an Eastern U.S. Copper Mine. http://www.wvu.edu/ agexten/landrec/2003TFS/Faulkner.pdf August 31, 2004. West Virginia University Extension Service

Feijtel, T.C., R.D. DeLaune and W.H. Patrick, Jr. 1989. Carbon, Nitrogen and Micronutrient Dynamics in Gulf Coast Marshes. Pp. 47-60. in R.R. Sharitz and J.W. Gibbons (Eds.), Freshwater Wetlands and Wildlife. CONF-8603101. United States Department of Energy, Oak Ridge, TN.

Fitch, M. and J. Burken. 2004. Constructed Wetlands for Metals Removal: 2003 Progress Report. http://www.hsrc.org/mw-metals03.pdf. University of Missouri-Rolla, MO.

Fude, L., B. Harris, M.M. Urrutia, and T.J. Beveridge. 1994. Reduction of Cr(VI) by a Consortium of Sulfate-Reducing Bacteria (SRB III). Appl. Environ. Microbiol., 60: 1525-31.

Giblin, A.E. 1985. Comparisons of the Processing of Elements by Ecosystems, II: Metals. in P.J. Godfrey et al. (Eds.), Ecological Considerations in Wetlands Treatment of Municipal Wastewaters. Van Nostrand Reinhold, New York. 
Gladden, J.B., E.A. Nelson, W.L. Specht, J.A. Bowers, T.H. Harris, S.M. Harmon, and J.H. Rodgers. 2003. Presentation at the Southeast Environmental Management Association. Augusta, GA, April 23, 2003.

Hendrey, G.R., J. Clinton, K. Blumer, and K. Lewin. 1979. Lowland Recharge Project Operations Physical, Chemical, and Biological Changes 1975-1978, Final report to the Town of Brookhaven. Brookhaven National Laboratory, Brookhaven, N.Y.

Horsnail, R.F., I. Nichol, and J.S. Webb. 1969. Influence of Variations in the Surface Environments on Metal Distribution in Drainage Sediments. Q. J. Colo. School of Mines, 64: 307-22.

Hurtado, D.. 2004. Wetlands (and aquatic systems).

http://peacecorps.mtu.edu/danny/Wetland\%20Systems.htm. September 24, 2004. Michigan

Technological University. Houghton, Michigan.

Interstate Technology \& Regulatory Council (ITRC). 2003. Technical and Regulatory Guidance Document for Constructed Treatment Wetlands. The Interstate Technology \& Regulatory Council Wetlands Team.

Kadlec, R.H. and G.A. Keoleian. 1986. Metal Ion Exchange on Peat, Chapter 5 in Peat and Water, pp. 61-93, ed. C.H. Fuchsman. Elsevier Applied Science.

Kadlec, R.H. and R.L. Knight. 1996. Treatment Wetlands. CRC Press, Boca Raton, FL.

Karathanasis, A.D. and Y.L. Thompson. 1995. Mineralogy of Iron Precipitates in a Constructed Acid Mine Drainage Wetland. Soil Sci. Am. J., 59: 1773-81.

Kleinmann, R., ed. 2000. Prediction of Water Quality at Surface Coal Mines. Morgantown, W.V.: Virginia National Mine Land Reclamation Center, West Virginia University.

Knox, A., D. Dunn, E. Nelson, W. Specht, and J. Seaman. 2004. Wastewater Treatment and Heavy Metals Removal in the A-01 Constructed Wetland: 2003 Report. WSRC-TR-2004-00228.

Westinghouse Savannah River Company, Aiken, SC.

Kuschk, P., A. Wießner, U. Kappelmeyer, E. Weißbrodt, M. Kästner, U. Stottmeister. 2003. Annual cycle of nitrogen removal by a pilot-scale subsurface horizontal flow in a constructed wetland under moderate climate. Water Research Volume: 37, Issue: 17, October, 2003, pp. 4236-4242.

Lehman, R.W., F.D. Mooney, J. H. Rogers, J.B. Gladden, C. Murray-Gulde, J.F. Bell. 2002. Wetlands for Industrial Wastewater Treatment at the Savannah River Site. Technical Paper \#0202. Prepared for the U.S. Department of Energy. Roy F. Weston, Inc.

Lorion, R. (2001). Constructed Wetlands: Passive Systems for Wastewater Treatment. Prepared for the US EPA Technology Innovation Office.

Mulamoottil, G., E.A. McBean, and F. Rovers, eds. 1999. Constructed Wetlands for the Treatment of Landfill Leachates. Boca Raton, Fla.: Lewis Publishers, Inc.

Mungur, A.S., R.B.E. Shutes, D.M. Revitt and M.A. House. 1997. An assessment of metal removal by a laboratory scale wetland. Water Science and Technology Vol 35 No 5 pp 125-133. IWA Publishing. 
Nelson, E.A., W.L. Specht, J.A. Bowers, and J.B. Gladden. 2002. Proceedings of the 2002 National Conference on Environmental Science and Technology. Battelle Press.

Noller, B.N., P.H. Woods, and B.J. Ross. 1994. Case Studies of Wetland Filtration of Mine Waste Water in Constructed and Naturally Occurring Systems in Northern Australia, Water Sci. Tech. 29: 257-66.

Oremland, R.S. 1994. Biogeochemical Transformations of Selenium in Anoxic Environments, Chapter 16 in Selenium in the Environment, pp. 389-419, eds. W. T. Frankenberger, Jr. and S. Benson. New York: Marcel Dekker.

Otte, M. L., C. C. Kearns, and M. O. Doyle. 1995. Accumulation of Arsenic and Zinc in the Rhizosphere of Wetland Plants, Bull. Environ. Contam. Toxicol. 55: 154-61.

NAHB Research Center (NAHB). 2004. Constructed Wetlands for Wastewater Treatment. http://www.toolbase.org/tertiaryT.asp?DocumentID=2158\&CategoryID=1402. August 27, 2004. Upper Marlboro, MD

Schiffer, D. M. 1989. Water quality Variability in a Central Florida Wetland Receiving Highway Runoff, Water: Laws and Management, ed. F. E. Davis. Bethesda, Md.: American Water Research Association.

Scholz, M. 2003. Performance predictions of mature experimental constructed wetlands which treat urban water receiving high loads of lead and copper. Water Research Vol: 37, Issue: 6, March, 2003, pp: 12701277.

Shutes, R.B.E., D.M. Revitt, L.N.L. Scholes, M. Forshaw and B. Winter. 2001. An Experimental Constructed Wetland System for the Treatment of Highway Runoff in the UK. Water Science and Technology 44:11-12, 571-578.

Sinicrope, T. L., R. Langis, R. M. Gersberg, M. J. Busanardo, and J. B. Zedler. 1992. Metal Removal by Wetland Mesocosms Subjected to Different Hydroperiods, Ecol. Eng. 1(4): 309-22.

Skousen, J. 2004. Overview of Passive Systems for Treating Acid Mine Drainage. http://www.wvu.edu/ agexten/landrec/passtrt/passtrt.htm . August 31, 2004. West Virginia University Extension Service.

Sobolewski, A. 1999. A Review of Processes Responsible for Metal Removal in Wetlands Treating Contaminated Mine Drainage, Int. J. Phytoremed. 1(1): 19-51.

Specht, W. L. 2004. Interoffice Memorandum to N. V. Halverson dated July 30, 2004. Westinghouse Savannah River Company, Aiken, SC.

Stumm, W. and J. Morgan. 1981. Aquatic Chemistry, 2nd edition. New York: Wiley.

Tchobanoglous, G. and F. L. Burton. 1991. Wastewater Engineering: Treatment, Disposal and Reuse, 3rd edition. New York: McGraw-Hill.

Tipping, E. and M. A. Hurley. 1992. A Unifying Model of Cation Binding by Humic Substances. Geochim. Cosmochim. Acta 56: 3627-41.

United States Department of Agriculture (USDA). 1995. Handbook of Constructed Wetlands. A Guide to Creating Wetlands for: Agricultural Wastewater, Domestic Wastewater, Coal Mine Drainage, Storm 
water in the Mid-Atlantic Region. Volume 1: General Considerations. USDA-Natural Resources Conservation Service/US EPA-Region III/Pennsylvania Department of Natural Resources. Washington, D.C.

United States Environmental Protection Agency (USEPA). 1988. Design Manual: Constructed Wetlands and Aquatic Plant Systems for Municipal Wastewater Treatment. EPA 625-1-88-022. U.S. EPA Office of Research and Development, Center for Environmental Research Information. Cincinnati, $\mathrm{OH}$.

United States Environmental Protection Agency (USEPA). 1993a. Created and Natural Wetlands for Controlling Nonpoint Source Pollution, ed. R.K. Olsen. Boca Raton, FL.

United States Environmental Protection Agency (USEPA). 1993b. Subsurface Flow Constructed Wetlands for Waste Water Treatment: A Technology Assessment. EPA 832-R-93-008. EPA Office of Water. Washington, D.C.

United States Environmental Protection Agency (USEPA). 1993c. Constructed Wetlands for Wastewater Treatment and Wildlife Habitat: 17 Case Studies. EPA832-R-93-005. EPA Office of Water.

Washington, D.C.

United States Environmental Protection Agency (USEPA). 2000a. EPA Manual - Constructed Wetlands Treatment of Municipal Wastewaters, EPA/625/R-99/010. EPA Office of Research and Development, Cincinnati, Ohio.

United States Environmental Protection Agency (USEPA). 2000b. Wastewater Technology Fact Sheet Wetlands: Subsurface Flow, EPA 832-F-00-023. EPA Office of Water, Washington D.C.

United States Environmental Protection Agency (USEPA). 2000c. Wastewater Technology Fact Sheet: Free Water Surface Wetlands, EPA 832-F-00-024. EPA Office of Water, Washington D.C.

Wieder, R. K. 1989. A Survey of Constructed Wetlands for Acid Coal Mine Drainage Treatment in The Eastern United States. Wetlands 9: 299-315.

Wood, A. 1995. Constructed wetlands in water pollution control: fundamentals to their understanding. Water Sci Technol 32(3):21-9.

Water Pollution Control Federation (WPCF). 1990. Manual of Practice FD-16, Chapter 9. Alexandria, VA. 